\title{
Цукровий діабет і COVID-19: сучасні погляди на \\ патогенетичні питання клініки та терапії
}

B.I. Цимбалюк', М.Д. Тронько, Ю.Г. Антипкін ${ }^{3}$, B.B. Попова

\footnotetext{
' Національна академія медичних наук України

2 ДУ «Інститут ендокринології та обміну речовин ім. В.П. Комісаренка НАМН України»

${ }^{3}$ ДУ «Інститут педіатрії, акушерства і гінекології ім. акад. О.М. Лук'янової НАМН України»
}

\begin{abstract}
Резюме. Пацієнти з цукровим діабетом (ЦД) знаходяться в центрі уваги з ранніх стадій пандемії COVID-19, оскільки епідеміологічні дані показують, що вони схильні до підвищеного ризику важких клінічних наслідків. Водночас як глобальна пандемія COVID-19 продовжує розвиватися, стає все більш очевидним, що зв'язок між COVID-19 і ЦД $€$ складною патофізіологічною взаємодією. Наслідки COVID-19 важчі в пацієнтів із ЦД, який здатний прискорити виникнення гострих метаболічних ускладнень, таких як діабетичний кетоацидоз і гіперглікемія. Механізми, які лежать в основі цих зв'язків залишаються нез'ясованими, але вони, очевидно, включають рецептор ангіотензинперетворюючого ферменту 2 (АПФ2), сайт зв'язування для коронавірусу 2 важкого гострого респіраторного синдрому (SARS-CoV-2), що експресується в ключових метаболічних органах, зокрема, у $\beta$-клітинах підшлункової залози (ПШ3). Потенційно тропізм SARS-CoV-2 до $\beta$-клітин може призвести до пошкодження клітин і порушення секреції інсуліну, викликаючи гіперглікемію і кетоацидоз. Розуміння двонапрямної взаємодії між ЦД і COVID-19 буде мати вирішальне значення для профілактики та лікування пацієнтів із ЦД. Наявні епідеміологічні дані про COVID-19 не підтверджують гіпотезу про те, що пацієнти з ЦД схильні до підвищеного ризику інфікування порівняно із загальною популяцією. На сьогодні встановлено, що декомпенсований ЦД $є$ незалежним чинником, який обтяжує перебіг коронавірусної інфекції та вірогідно підвищує ризики фатального наслідку захворювання. В огляді представлена квінтесенція еволюції поглядів патогенетичних і клінічних аспектів розуміння механізмів цього патологічного тандему, а також терапевтичних стратегій лікування пацієнтів із COVID-19 і ЦД. Оскільки захворюваність на ЦД продовжує зростати в усьому світі, наразі, більш ніж коли-небудь, профілактика ЦД та боротьба з ним повинні стати пріоритетом систем охорони здоров'я всіх країн світу.
\end{abstract}

Ключові слова: COVID-19, цукровий діабет, патогенез, клініка, лікування.

Місто Ухань (Wǔhàn), провінція Хубей (Húběi), Китай, було відправною точкою вірусної пандемії [1]. COVID-19 - це вірусне інфекційне захворювання, яке

(с) В.І. Цимбалюк, М.Д. Тронько, Ю.Г. Антипкін, В.В. Попова викликає SARS-CoV-2, що є частиною родини Coronaviridae, яке раніше також викликало епідемію SARS у 2002 році та епідемію MERS у 2008 [2-5]. Це одноланцюговий вірус 3 оболонковою РНК, названий на честь його 
COVID-19

короноподібних виступів на поверхні, який можна виявити за допомогою електронної мікроскопії [6].

У всьому світі зареєстровано понад $170 \quad 000 \quad 000$ підтверджених випадків COVID-19. Оновлена кількість випадків захворювання в англомовних джерелах у вигляді інтерактивної карти 3 висвітленням підтверджених випадків в усьому світі викладена на сайтах Всесвітньої організації охорони здоров'я (World Health Organization, WHO) та Європейського центру з профілактики та контролю захворювань (European Centre for Disease Prevention and Control, ECDC) [7].

Для написання огляду літератури було здійснено пошук статей у базах даних PubMed i Google Scholar до 10 травня 2021 року за такими ключовими словами: «SARS-CoV-2», «COVID-19», «коронавірусна інфекція», «патогенез», «підшлункова залоза», «клінічні особливості», «діагностика», «лікування», «діабет». Ми також отримали повний текст відповідних перехресних посилань за результатами пошуку. Крім того, ми отримали доступ до наявної на цей час наукової літератури та рекомендацій на вебсайтах Всесвітньої організації охорони здоров'я та Центрів із контролю і профілактики захворювань (Centers for Disease Control and Prevention, CDC).

COVID-19 - захворювання 3 величезною контагіозністю і високою смертністю, яке виникло нещодавно. Нові дані свідчать про те, що ЦД є одним із найпоширеніших супутніх захворювань у пацієнтів із COVID-19, причинно-наслідковий зв'язок яких ще не встановлено, а раніше ЦД розглядається як чинник ризику несприятливих наслідків COVID-19.

ЦД - це метаболічне захворювання, що проявляється хронічно високою концентрацією глюкози крові в організмі. Поширеність ЦД в усьому світі різко зросла: у 2019 р. на це захворювання страждали 463 мільйони людей, з яких 95\% складати пацієнти з ЦД 2-го типу (ЦД2) [8]. Зараз у багатьох пацієнтів із Цд захворювання не діагностується. Терапевтичні інтервенції значно знижують частоту виникнення ускладнень захворювання, що робить необхідним виявлення ЦД на ранній стадії його розвитку.

У пацієнтів із COVID-19 на тлі ЦД вища ймовірність поганого прогнозу і смерті. 3 огляду на високу захворюваність на ЦД в усьому світі, ці люди складають значну частину населення, сприйнятливого до COVID-19. Декілька чинників пов'язані з вищим ризиком смертності від COVID-19, а саме: чоловіча стать, похилий вік, гіпертензія, цукровий діабет, ожиріння, серцево-судинні захворювання (СС3), хронічна обструктивна хвороба легенів і рак [9].

У нещодавньому дослідженні повідомлялося про 10\% смертність серед пацієнтів із COVID-19, які страждають на ЦД [10]. Для нових діагностованих випадків ЦД рівень смертності та потреби в штучній вентиляції легень були значно вищими, ніж у людей з уже наявним захворюванням. На пацієнтів з інфекцією COVID-19 також негативно впливає неконтрольована гіперглікемія, яка значно підвищує потенційний ризик ускладнень.

Прозапальний статус, ослаблення вродженої імунної відповіді, підвищений рівень експресії АПФ2, поряд із судинною дисфункцією і протромботичним станом у людей із ЦД, імовірно, сприяють більшій сприйнятливості до інфекції SARS-CoV-2 і погіршенню прогнозу. 3 другого боку, активне запалення, пошкодження острівців Лангерганса, викликане вірусною інфекцією, і лікування глюкокортикоїдами можуть, своєю чергою, призвести до порушення регуляції глюкози в людей із ЦД, що ускладнює перебіг захворювання. Тому регуляція глікемії в людей із COVID-19, особливо з важким захворюванням, має велике значення [11].

На сьогодні питання взаємозв'язку і взаємозумовленості COVID-19 і коморбідних захворювань є найбільш дискусійними серед усіх патогенетичних аспектів нової коронавірусної інфекції. Хоча на цей момент патогенез COVID-19 до кінця не вивчений, він може бути схожим на патогенез вірусу SARS-CoV.

Відзначено, що найважчі й смертельні випадки COVID-19 мали місце в людей літнього віку або в пацієнтів із супутніми захворюваннями, зокрема, із ССЗ, ЦД, хронічними захворюваннями легень, нирок, гіпертонії та онкологічними захворюваннями [12-15]. За даними Всесвітньої організації охорони здоров'я, рівень смертності серед пацієнтів 3 артеріальною гіпертонією досягає 8\%, серед пацієнтів із ЦД - 9\%. В Американському дослідженні показано, що серед 1122 пацієнтів, 
госпіталізованих із приводу COVID-19, рівень смертності під час перебування в клініці серед тих, хто страждає на ЦД або гіперглікемію, був у чотири рази вищим $(28,8 \%)$, ніж у пацієнтів із нормальним рівнем глюкози $(6,2 \%)$ [16].

Зниження ймовірності ускладнень і смертності від усіх причин також було пов'язано 3 хорошою регуляцією глікемії [17]. А.А. Al Hayek та співавт. у результаті дослідження чинників, які можуть підвищити ризик госпіталізації пацієнтів із COVID-19 та ЦД, повідомили, що госпіталізація пацієнтів не залежала від високого рівня глікованого гемоглобіну в пацієнтів Саудівської Аравії [18].

У метааналізі Китайських дослідників показано, що високий рівень глікованого гемоглобіну є предиктором госпітальної смертності пацієнтів із COVID-19 [19]. Особи з підвищеним рівнем глікованого гемоглобіну схильні до підвищеного ризику COVID-19 повинні виконувати рекомендації лікаря і регулярно точно відстежувати та регулювати метаболізм глюкози $[17,19]$. Було висловлено припущення, що ЦД може посилювати тяжкість інфекціï SARS-CoV-2 різними шляхами, які сприяють розвитку кінцевих продуктів глікування (глікації), токсичності глюкози, ендотеліїту, пошкодженню життєво важливих органів і летального наслідку [20].

Коронавірус, що викликає захворювання COVID-19, потрапляє в клітини-мішені завдяки рецепторам особливого білка - АПФ2, який вірус використовує як вхідні ворота. Водночас АПФ2 є мішенню цілої низки лікарських препаратів (інгібіторів АПФ і блокаторів рецепторів ангіотензину 2 - сартанів), які широко застосовуються в пацієнтів із СС3, артеріальною гіпертензією та ЦД.

\section{Патофізіологічні аспекти COVID-19 і Цд}

COVID-19 та ЦД пов'язані з гострим і хронічним запаленням, i, відповідно, можуть впливати один на одного з точки зору клінічного прогресування й наслідку. Таким чином, необхідні подальші дослідження як взаємовпливу цих захворювань, так і розробки терапевтичного підходу до лікування ЦД на тлі COVID-19.

Хронічна гіперглікемія є основним метаболічним порушенням при ЦД і викликає глюкозотоксичність тканин організму з утворенням кінцевих продуктів глікації [21]. Ці механізми відповідальні за розвиток хронічних ускладнень ЦД. Ранні дослідження показали, що пацієнти літнього віку з хронічними захворюваннями, зокрема з ЦД, схильні до більшого ризику розвитку важкого перебігу COVID-19 і підвищеної смертності [12, 13, 22]. Крім того, за останніми даними, Цд займає пріоритетне місце щодо смертності серед госпіталізованих пацієнтів [23].

Як відомо, ЦД - це хронічний запальний стан, що характеризується множинними метаболічними й судинними порушеннями, які детермінують реакцію на патогенні мікроорганізми [24]. Крім того, ЦД характеризується високою прозапальною цитокіновою відповіддю, особливо інтерлейкінів 1 і 6 та фактора некрозу пухлин $\alpha$ за відсутності екзогенної імуностимуляції. За наявності ж зовнішнього тригера в пацієнтів із ЦД виникає ситуація гіперцитокінемії, цитокінового шторму, на тлі COVID-19, ускладненого гострим респіраторним дистрес-синдромом (ГРДС, Acute respiratory distress syndrome, ARDS) і системною поліорганною недостатністю [25]. Гіперглікемія і резистентність до інсуліну сприяють збільшенню синтезу кінцевих продуктів глікування (глікації) та різкого підвищення секреції прозапальних цитокінів, наростання рівня окисного стресу, а також стимулюють вироблення молекул адгезії, які опосередковують запалення тканин $[24,26]$.

Згідно з даними, отриманими з моменту появи COVID-19, це захворювання має дві фази, які перекриваються. Перша фаза значною мірою характеризується непропорційною реакцією імунітету, яка викликає цитокіновий шторм i, як наслідок, завдає значної шкоди організму. Крім того, запалення викликає вироблення значної кількості чинників, пов’язаних з ініціацією каскаду коагуляції, що призводить до виникнення тромбів і пов'язаного з ними синдрому дисемінованого внутрішньосудинного згортання крові, стану, дуже схожого на той, який спостерігається під час сепсису [27]. Цей запальний процес може стати основним механізмом, який призводить до більшої схильності до інфекцій із гіршими наслідками в пацієнтів із ЦД [26].

Деякі дефекти імунітету розглядаються в тісному зв’язку з гіперглікемією. 3 другого боку, погано контрольований ЦД пов'язаний 
COVID-19

iз пригніченням проліферативної відповіді лімфоцитів на різні тригери [25], а також із порушенням функцій моноцитів/макрофагів і нейтрофілів [24]. Похилий вік пов'язаний із дефектами функції Т- і В-клітин та надлишковою дисфункціональною продукцією маркерів запалення, тобто ЦД2 автономно або в поєднанні з літнім віком, гіпертонією i/або СС3 може сприяти недостатньому контролю реплікації SARS-CoV-2 і тривалішій прозапальній відповіді, що може призвести до фатального кінця [14, 28].

Раніше висувалися гіпотези, що приймання інгібіторів ангіотензинперетворювального ферменту (іАПФ) і блокаторів рецепторів ангіотензину (БРА) може підвищувати ризик захворювання на вірусну інфекцію. Щоб потрапити всередину клітини, вірус SARS-CoV-2 зв'язується через свій білок $\mathrm{S}$ із рецепторами АПФ2, розташованими на мембранах альвеолярних клітин легенів, нирок, міокарда і кишківника, тому саме ці органи може вражати новий коронавірус. Рецептор АПФ2 дуже важливий для проникнення SARS-CoV-2 в клітини. Він у достатній кількості експресується епітеліальними клітинами легень, кишківника, нирок і судин.

X.C. Li, та співавт. [29] показали, що пацієнти з ЦД також експресують великі концентрації АПФ2, і його рівень значно підвищується в тих, хто приймає іАПФ або БРА. Була висловлена гіпотеза про те, що поліморфізм АПФ2 пов'язаний із деякими неінфекційними захворюваннями, такими як ЦД, гіпертонія, інсульт і генетичною схильністю до розвитку інфекції SARS-CoV-2 [3]. Оскільки реакція імунофарбування на АПФ2 виявила його присутність в острівцях ПШЗ, було висловлено припущення, що SARS-CoV може пошкоджувати $\beta$-клітини острівців Лангерганса i викликати маніфестацію автоімунного ЦД 1-го типу [30, 31].

Як зазначалося вище, роль АПФ2 в патогенезі ЦД у поєднанні з COVID-19 широко обговорювалася в останніх публікаціях і на сьогодні вже частково вивчена. 3 огляду на те, що АПФ2 є функціональним рецептором для SARS-CoV-2 і його експресійні рівні можуть бути підвищені, деякі автори раніше стверджували, що препарати іАПФ і БРА можуть спричиняти негативний вплив на перебіг і наслідок захворювання в пацієнтів із COVID-19 [32]. На противагу цьому твердженню, інші дослідники стверджують, що іАПФ і БРА можуть бути досить ефективними в терапії коронавірусної інфекції [33], оскільки SARS-CoV і його вірусний Spike білок після з'єднання з функціональним рецептором для SARS-CoV-2 АПФ2, знижують експресію АПФ2 в наступні стадії захворювання після досягнення вкрай високого рівня вірусемії [34].

Як відомо, АПФ розщеплює ангіотензин (Ang) I до Ang II. Ang II зв’язується з рецептором Ang II і потім опосередковує численні системні ефекти, такі як стимулювання вазоконстрикції, забезпечення нормоволемії, регуляція імунної системи та місцеві ефекти в серцево-судинній системі. У ренін-ангіотензин-альдостероновій системі (РААС) АПФ2 виконує протилежну АПФ роль. АПФ2 каталізує перетворення Ang I в Ang-(1-9) i Ang II в Ang-(1-7). Ang-(1-7) зв'язується 3 рецептором Mas для опосередкування різних ефектів, у тому числі: вазорелаксацію, кардіозахист, антиоксидантну [35] і протизапальну дії [36] та інгібування індукованої Ang II передачі сигналів [37, 38]. Вісь АПФ2Ang-(1-7) вважається важливою терапевтичною мішенню при СС3 [39]. Додаткові дані показали, що рівень АПФ2 підвищується в пацієнтів із ЦД1 і ЦД2, гіпертонією, серцевою недостатністю і хронічними захворюваннями нирок [40-42]. Причина підвищеної експресії АПФ2 в цих пацієнтів - захисна відповідь для протидії впливу несприятливих наслідків Ang II. Експресія АПФ2 більш виражена в ендокринній тканині ПШЗ порівняно з екзокринною тканиною [43]. Ступінь пошкодження тканин SARS-CoV обумовлюється рівнем експресії тканинного АПФ2. Таким чином, віруси SARS-CoV можуть пошкоджувати острівці ПШЗ і викликати дебют ЦД [44].

Якщо імунна система не в змозі перемогти інфекцію, SARS-CoV-2 буде масово реплікуватися, займати клітинний АПФ2 і руйнувати клітини пацієнта. Як наслідок, система Ang IIAT1 не може бути неактивною. У результаті маніфестує цитокіновий шторм, і в кінцевому підсумку дихальна система, серцево-судинна система та інші органи втрачають свої функції.

Клінічні дані показали, що серед стаціонарних пацієнтів із COVID-19 близько $30 \%$ 
мають основні захворювання і підвищений ризик смерті. Найпоширенішою була гіпертонія, потім ЦД і ішемічна хвороба серця [14, 45]. Оскільки вісь Ang II-AT1 вже гіперактивна при цих захворюваннях, SARS-CoV-2 ще більше знижує вироблення функціонального АПФ2 [13, 46]. Отже, у пацієнтів із цими основними захворюваннями набагато швидше розвивається важкий перебіг хвороби та трансформується в критичний стан. Таким чином, рецептор АПФ2 виконує суперечливі функції в патофізіології інфекції SARS-CoV-2: одну, де АПФ2 полегшує захворювання як сайту зв'язування SARS-CoV-2, а іншу, де знижена експресія АПФ2 може сприяти важкому травматичному ураженню легень після інфікування [47].

На думку деяких авторів, експресія АПФ2 знижується в пацієнтів із ЦД, можливо, внаслідок глікування, ніж підвищеної схильності до важких пошкоджень легенів і маніфестації ГРДС у пацієнтів із ЦД на тлі COVID-19 [48, 49]. Отже, надекспресія АПФ2 буде контрпродуктивною в пацієнтів iз COVID-19, оскільки SARS-CoV-2 використовує АПФ2 як рецептор для проникнення в пневмоцити господаря [50]. Експресія АПФ2 помітно підвищена в пацієнтів із ЦД і гіпертонією, які отримують іАПФ або БРА, як адаптивну відповідь для протидії підвищеним рівням Ang II і Ang I. Раніше вважалося, що використання АПФ2-стимулюючих препаратів сприяє проникненню SARS-CoV-2 в пневмоцити та може призводити до важчих і смертельних захворювань [51].

Нині використання препаратів - інгібіторів РААС повністю відновлено, оскільки експресія АПФ2 при їх застосуванні є одним із захисних механізмів у функціонуванні РААС. Вірус зв'язується 3 клітинами через свій тримерний пік глікопротеїн, що робить цей білок ключовою мішенню для потенційної терапії та діагностики [50]. Таким чином, надлишкова експресія АПФ2, хоча і сприяє проникненню SARS-CoV-2, все ж відіграє протекторну роль для тканини легенів, як і для інших органів і систем, оскільки перешкоджає запуску патологічного каскаду системних реакцій, зумовлених зламом РААС, що призводять до поліорганної дисфункції. ЦД пов'язаний із гіршими наслідками в пацієнтів із COVID-19, проте, сприйнятливість до інфекції SARSCoV-2 вища в людей із декомпенсованим ЦД. Згідно з дослідженнями, поширеність ЦД серед інфікованих вірусом COVID-19, приблизно така сама, як і в загальній популяції [52, 53].

Як раніше було встановлено, АПФ2 і дипептидилпептидаза-4 (ДПП-4) є рецепторами для проникнення коронавірусу. У нещодавніх публікаціях велася широка дискусія щодо можливості ДПП-4 бути рецептором для COVID-19. У серії останніх досліджень висловлено припущення, що ДПП-4 є основним рецептором близькосхідного респіраторного коронавірусного синдрому (Middle East respiratory syndrome-related coronavirus, MERS-CoV), але не SARS-CoV-2, тобто не рецептором COVID-19 [54].

Фермент ДПП-4 є трансмембранним глікопротеїном II типу, що експресується в багатьох тканинах, включаючи імунні клітини. ДПП-4 також відома як CD26, білок клітинної поверхні лімфоцитів, який відіграє важливу роль у функціонуванні Т-клітин [55]. ДПП-4/ CD26 присутня й активна в легенях і конститутивно експресується фібробластами легенів, де вона спричиняє проліферативну дію. ДПП-4/CD26 також є маркером міграції та функціональної активації фібробластів, включаючи синтез колагену та секрецію запальних цитокінів [56].

Хоча функції ДПП-4 ще не повністю вивчені, вона відіграє основну роль у метаболізмі глюкози та інсуліну. ДПП-4 руйнує інкретіни, такі як глюкагоноподібний пептид 1 (ГПП-1) і глюкозозалежний інсулінотропний поліпептид, що в кінцевому підсумку призводить до зниження секреції інсуліну та порушення метаболізму вісцеральної жирової тканини. ДПП-4 регулює постпрандіальну глікемію за допомогою деградації ГПП-1. Експресія ДПП-4 вища у вісцеральній жировій тканині та безпосередньо корелює із запаленням адипоцитів і резистентністю до інсуліну. ДПП-4 також відіграє важливу роль в імунній регуляції, активуючи Т-клітини, експресію CD86 і шлях нуклеарного фактора «каппа-би» (nuclear factor kappa-light-chain-enhancer of activated B cells, NF-kB).

Оскільки інгібітори ДПП-4 зазвичай застосовуються в лікуванні ЦД у всьому світі, у низці досліджень прозвучало припущення про 
COVID-19

можливе використання ДПП-4 як рецептора для SARS-CoV-2 i, відповідно, гіпотетичної можливості потенціювання ресурсної захисної дії інгібіторів ДПП проти COVID-19 [57].

D.J. Drucker постулює, що рівні ГПП-1 та активність ДПП-4 регулюються інфекцією і запаленням, i, своєю чергою, інгібітори ДПП-4 й агоністи рецептора ГПП-1 також можуть модулювати запалення. АПФ2 і ДПП-4, є встановленими перетворювачами метаболічних сигналів і шляхів, що регулюють запалення, фізіологію нирок і серцево-судинної системи та гомеостаз глюкози [58].

Дипептидилпептидаза, загальна фармакологічна мішень для ЦД. 3 другого боку, ДПП-4 проявляє прозапальну активність. Хоча зв'язок SARS-CoV-2 і ДПП-4 залишається ще нез'ясованим, використання інгібіторів ДПП-4 може надати терапевтичні можливості для лікування пацієнтів із ЦД i COVID-19 в клінічній практиці $[59,60]$.

Терапевтична тактика в пацієнтів із ЦД на тлі COVID-19

За даними Американської діабетичної асоціації (American Diabetes Association, ADA), пацієнти з ЦД мають вищий рівень ускладнень і смертності від COVID-19, оскільки ЦД спочатку асоційований із порушенням імунної відповіді, що робить їх сприйнятливішими до інфекцій. 3 другого боку, вважається, що гіперглікемія в пацієнтів із ЦД може бути причиною дисфункції імунної відповіді, що призводить до нездатності контролювати поширення патогенних мікроорганізмів i робить таких хворих сприйнятливішими до інфекцій, що повністю узгоджується з твердженням Ritesh Gupta про те, що терапевтична курація ЦД передбачає, перш за все, хороший глікемічний контроль при маніфестації COVID-19 [61].

ЦД асоціюється 3 поганим прогнозом при багатьох вірусних інфекціях, зокрема й при коронавірусній. Механізми, що запропоновані для цієї очевидної асоціації COVID-19 і ЦД, включають численні порушення аж до повного зламу вродженої імунної системи. Крім того, іАПФ і БРА, які широко використовуються в людей із ЦД, є сполучною ланкою між COVID-19 і ЦД. іАПФ/БРА призводять до посилення регулювання АПФ2, який конститутивно експресується в легенях, серці, кишківнику, нирках і судинному ендотелії $[62,63]$.
Наявні епідеміологічні дані про COVID-19 не підтверджують гіпотезу про те, що пацієнти із ЦД схильні до підвищеного ризику інфікування порівняно із загальною популяцією [51, 62], і очевидно, що ЦД, особливо коли він погано контролюється, наражає хворих на велику небезпеку смертельного наслідку $[15,64,65]$.

Нещодавно було висунуто припущення, що агоністи рецепторів глюкагоноподібного пептиду-1 (Glucagon-like peptide-1 receptor agonists, GLP-1Ra) та інгібітори натрій-глюкозного контранспортера 2 (Sodium/glucose cotransporter-2 inhibitors, SGLT-2i) піоглітазон і навіть інсулін можуть викликати надмірну експресію рецептора АПФ2 [66, 67], що підвищує ризик розвитку в пацієнтів із Цд серйозніших наслідків при зараженні. Ця проблема має велике значення, оскільки сьогодні стверджується, що оптимальний глікемічний контроль при ЦД необхідний, як ніколи раніше $[67,68]$.

Коли порушувалось питання про можливу індукцію експресії АПФ2 щодо використання іАПФ або БРА, Свропейське агентство лікарських засобів (European Medicines Agency, EMA) та кілька наукових товариств наголосили, що поки це є лише гіпотезою, яка виходить із деяких досліджень in vitro i ще не підтверджена будь-якими клінічними даними в людей, уражених COVID-19, тому абсолютно невиправдано припиняти використання таких ліків, які дуже ефективні й безпечні для порятунку життя людей, що було підтверджено в подальших рекомендаціях [69]. У низці останніх публікацій стверджується, що подібні рекомендації терміново необхідно адаптувати до застосовування антигіперглікемічної терапії [70]. Наразі, деякі цукрознижувальні препарати можуть мати побічні дії при використанні [71].

Зараз багатьма дослідниками розглядаються можливості перегляду призначення цукрознижувальної терапії пацієнтам із ЦД i COVID-19. Інсулін $є$ безпечним вибором у більшості випадків і залишається єдиною терапією для людей із ЦД1 й може розглядатися як чудова альтернатива для людей із ЦД2, що мають поганий глікемічний контроль. На думку деяких вчених, метформін і препарати сульфанілсечовини не взаємодіють з АПФ2 й 
можуть бути безпечно продовжені при легкому перебігу COVID-19 [72].

Навпаки, в недавніх публікаціях показано, що піоглітазон активує експресію АПФ2 в чутливих до інсуліну тканинах у щурів і знижує активність дизінтегрина та металопротеази 17 (A disintegrin and metalloprotease 17, ADAM-17) у скелетних м'язах людини [73-75]. Хоча надзвичайно важливо стежити за тим, щоб пацієнти контролювали рівень глюкози в крові амбулаторно для запобігання важкої інфекції COVID-19, є також міркування щодо використання ліків за амбулаторних умов [76, 77]. Рекомендується розглянути питання про припинення приймання метформіну, особливо якщо в пацієнта спостерігаються більш серйозні симптоми та є ризик зневоднення, оскільки це може збільшити ймовірність лактоацидозу або пошкодження печінки [78, 79].

Інгібітори SGLT2 також рекомендується скасувати через ризик зменшення об'єму та виникнення діабетичного кетоацидозу в пацієнтів із COVID-19 [77, 80]. Ризик еуглікемічного діабетичного кетоацидозу з інгібіторами SGLT2 спостерігається навіть через кілька днів після відміни препарату [80]. Можна продовжити прийом PA GLP-1 і інгібіторів ДПП-4. Пацієнтам слід рекомендувати уникати зневоднення і регулярно їсти, щоб запобігти серйозним захворюванням, які пов’язані зі зневодненням. Терапію інсуліном не можна припиняти, а пацієнту слід регулярніше контролювати рівень глюкози в крові (кожні 2-4 години). Може знадобитися коригування дози інсуліну [77, 81].

Ефективність терапії GLP-1Ra i SGLT-2i для профілактики СС3 і захворювань нирок у хворих на ЦД добре відома [82], що неймовірно важливо для збереження гарної функціональної активності серцево-судинної та ниркової систем, особливо під час пандеміі. Пацієнти з ССЗ або нирковими захворюваннями мають гірший прогноз під час COVID-19 [14], тому необхідно зберегти цілісність і функціональність ниркової та серцево-судинної систем у пацієнтів із ЦД, які можуть бути порушені інфекцією COVID-19. Хоча немає конкретних даних про застосування інгібітора SGLT2 під час інфекції COVID-19, бажано не приймати його в стадії гострого періоду захворювання через підвищений ризик дегідратації та діабетичного кетоацидозу [83, 84].
Запалення відіграє ключову роль під час інфекціï SARS-CoV-2 [85]. ДПП-4 експресується в багатьох тканинах, зокрема в дихальних шляхах, що становить потенційну мішень для зниження тяжкості COVID-19 у пацієнтів із ЦД, оскільки є метою терапії на основі інкретинів, і це спонукало до дискусії про те, чи можуть інгібітори ДПП-4, які зараз використовуються для лікування людей із ЦД2, бути ефективними в пацієнтів із ЦД і SARS-CoV-2 [86].

Деякими авторами висловлюється припущення, що потенційна протизапальна роль інгібіторів ДПП-4 порушує питання, чи може модуляція ДПП-4 допомогти компенсувати цитокіно-опосередковані гострі респіраторні ускладнення COVID-19 [87]. Інгібітори ДПП-4 пов’язані з низьким ризиком гіпоглікемії та відносно безпечні. При додаванні до базального інсуліну вони покращують глікемічний контроль без збільшення ризику гіпоглікемії навіть серед госпіталізованих пацієнтів [88]. Але ці препарати мають меншу терапевтичну користь у пацієнтів із важкою формою COVID-19. Хоча пацієнти з легкими симптомами можуть продовжувати приймати інгібітори ДПП-4, проте їх необхідно скасовувати при гострих важких захворюваннях і замінювати на інсулін.

Крім того, слід підкреслити, що аналоги рецепторів ГПП-1 протягом багатьох років демонстрували значні протизапальні та антиадипогенні ефекти, знижуючи резистентність до інсуліну [89, 90]. Ефект зниження запального стресу та периферичної резистентності до інсуліну шляхом ослаблення асоціації з макрофагами за допомогою ГПП-1-залежної передачі сигналів і регулювання поляризації макрофагів М1/M2, було описано з пригніченням ДПП-4 і активацією ГПП-1 [91]. Аналогічні дані про вплив на запалення також отримані для SGLT-2i [92] і піоглітазону [93].

Терапію агоністом рецептора ГПП-1, імовірно, слід тимчасово припинити в пацієнтів із гемодинамічною нестабільністю, нирковою та шлунково-кишковою дисфункціями. Лікування GLP-1RA може викликати шлунковокишкові побічні ефекти, що супроводжуються гіповолемією і регургітацією [94]. Під час важкого перебігу COVID-19 при використанні препаратів сульфанілсечовини складно контролювати рівень глюкози в крові. Тому в таких 
COVID-19

пацієнтів препарати сульфанілсечовини слід замінювати на інсулін. Тіазолідиндіони, 30крема, піоглітазон, є менш сприятливим варіантом для стаціонарного лікування важкохворих пацієнтів через затримку рідини й наростальний системний набряк. Вони також протипоказані пацієнтам із гемодинамічною нестабільністю, печінковою або серцевою дисфункціями [95].

Наразі немає прямих доказів за або проти продовження приймання статинів у пацієнтів із ЦД і COVID-19. Є попередні повідомлення про підвищені рівні ферментів печінки й м'язів, асоційованих із COVID-19, хоча важкі захворювання печінки або рабдоміоліз не характерні для коронавірусної інфекції [96]. Тому зараз постулюється персоналізована терапія пацієнтів із Цд і COVID-19 з урахуванням показань до терапії статинами, а також можливих лікарських взаємодій із противірусними препаратами.

Отже, в очікуванні конкретних клінічних даних, безумовно, необхідний баланс між потенційними небезпечними ефектами застосування в клініці деяких ліків, підтвердженими в основному експериментальними даними, і доведеним впливом препаратів на серцевосудинну і ниркову системи, а також їхнім потенціалом протизапальної дії [97].

Аналізуючи клінічний досвід терапії пацієнтів із ЦД під час пандемії COVID-19, R. Pal i S.K. Bhadada підкреслили, що протималярійний препарат гідроксихлорохін використовувався як профілактика проти COVID-19 у багатьох країнах; проте, у разі одночасного введення гідроксихлорохіну разом з іншими антидіабетичними препаратами дози супутньої терапії повинні бути переглянуті, особливо в пацієнтів із вищим гіпоглікемічним ризиком [66].

Дійсно, вже понад 30 років відомо, що гідроксихлорохін має гіпоглікемічний ефект, який може спровокувати важкі епізоди гіпоглікеміï. G.D. Smith та співавт. описали значне поліпшення глікемічних показників у небагатьох пацієнтів із ЦД2, які отримували гідроксихлорохін [98]. Це відкриття було потім підтверджено A. Quatraro та співавт. у дослідженні, у якому описується ЦД2, який лікували інсуліном або глібенкламідом у комбінації з гідроксихлорохіном протягом 6 місяців.
Автори виявили значне зниження глікованого гемоглобіну - на 3,3\% порівняно з плацебо і зниження доз інсуліну на 30\% [99].

Зараз гідроксихлорохін у дозі 400 мг/добу схвалений у деяких країнах як додатковий антидіабетичний препарат третьої лінії після метформіну та препаратів сульфанілсечовини в людей із ЦД2 [100]. Препарат діє шляхом підвищення внутрішньоклітинного $\mathrm{pH}$, який пригнічує ферментативну деградацію інсуліну, що призводить до рециркуляції значної частини інсуліну в активній формі. Відповідно до його імуномодулювальних властивостей гідроксихлорохін також здатний зменшувати секрецію прозапальних цитокінів, особливо фактора некрозу пухлин $\alpha$ та інтерлейкіну-6, знижуючи резистентність до інсуліну.

Цікаво, що гідроксихлорохін ефективний проти SARS-CoV-2 in vitro і знижує вірусне навантаження в пацієнтів із COVID-19. Механізми дії включають порушення зв’язування між клітинним АПФ2 і шиповим вірусним білком SARS-CoV-2 шляхом підвищення внутрішньоклітинного/ендосомального рН, а також інгібування презентації антигену, подальшого придушення активації Т-клітин і гіперсекреції прозапальних цитокінів, сприяючи запобіганню цитокінового шторму [101].

Хоча запалення пов'язане 3 порушенням рівня глюкози, основний механізм гіпоглікемічного ефекту гідроксихлорохіну все ж залишається до кінця не з'ясованим [102]. Описано, що хлорохін збільшує секреторну відповідь C-пептиду, потенційно відображаючи поліпшену функцію $\beta$-клітин ПШЗ [103]. Зниження внутрішньоклітинної деградації інсуліну та збільшення його накопичення також були визначені як можливі ефекти гідроксихлорохіну на експериментальних моделях [104].

3 огляду на попередні повідомлення про вплив хлорохіну/гідроксихлорохіну на метаболізм глюкози рекомендовано бути обачними при призначенні препарату пацієнтам з Цд i COVID-19. Коригування дози пероральних протидіабетичних препаратів та/або інсуліну може стати необхідним для запобігання можливих гіпоглікемічних подій [105].

Протималярійні препарати хлорохін і гідроксихлорохін використовувалися для лікування інфекції SARS-CoV-2 попри їхні потенційні побічні ефекти [106, 107]. Вважається, що 
два основних механізми дії гідроксихлорохіну полягають у його обмеженні розщеплення вірусного білка на ділянці зв’язування АПФ2 та його протизапальних та імуномодулювальних властивостей [108]. Гідроксихлорохін також знижує рівень глюкози в крові внаслідок підвищення чутливості до інсуліну і поліпшення функції $\beta$-клітин ПШЗ [109], що дозволило призначати гідроксихлорохін як протидіабетичний препарат у деяких країнах [110].

Отже, може знадобитися коригування раніше призначених протидіабетичних препаратів аби уникнути гіпоглікемії в рідкісних випадках у пацієнтів із ЦД, які приймають гідроксихлорохін [111-113]. Слід зазначити, що дослідження показали суперечливі результати щодо ефективності гідроксихлорохіну при лікуванні пацієнтів із COVID-19 [114, 115]. Необхідні краще сплановані дослідження для оцінки його терапевтичної ефективності [116].

В останніх роботах вірогідно встановлено, що гіперглікемія при госпіталізації - при діабетичному статусі - $є$ ключовим предиктором смерті та тяжкості COVID-19 серед некритичних пацієнтів. Імовірність смерті в людей 3 аномально високим рівнем глюкози була більше ніж у два рази вищою, ніж у людей iз нормальними показниками $(41,4 \%$ проти $15,7 \%)$. Також у них була підвищена потреба в апараті штучної вентиляції легенів і у відділенні інтенсивної терапії. Ці результати наочно демонструють простий і практичний спосіб стратифікації ризику смерті в госпіталізованих пацієнтів із COVID-19 [117].

Діабетична ретинопатія i кардіоміопатія є протипоказаннями для призначення гідроксихлорохіну. Отже, антигіперглікемічний ефект гідроксихлорохіну заслуговує на серйозне вивчення в подальших клінічних дослідженнях у пацієнтів із ЦД на тлі коронавірусної інфекції.

Інсулін порівняно з іншими препаратами, що знижують рівень глюкози, використовується переважно в госпіталізованих пацієнтів. Також у цих пацієнтів кращою стратегією лікування гіперглікемії є підшкірна інсулінова терапія інсуліном базальної або проміжної дії разом із болюсним інсуліном [118]. У таких пацієнтів можуть бути виправдані менш агресивні схеми введення інсуліну, спрямовані на просту мінімізацію глюкозурії, дегідратації та порушень електролітного балансу. Хоча не існує строгих рекомендацій щодо режиму інсуліну для контролю глікемії в критично важких пацієнтів, можуть використовуватися внутрішньовенні інфузї інсуліну і короткі або швидкодіючі болюси інсуліну. При визначенні дозування інсуліну слід враховувати тяжкість захворювання, стан харчування, супутні препарати й тенденцію до глікемічних коливань [119], тобто в пацієнтів із ЦД1 та COVID-19 і гіперглікемією важливо контролювати рівень глюкози й кетонів у крові, підтримувати гідратацію та продовжувати терапію інсуліном.

На сьогодні розроблені рекомендації щодо лікування інфекцій у пацієнтів із ЦД, які поширюються на пацієнтів, у яких також діагностований COVID-19. Загалом пацієнти з ЦД, особливо ті, чиє захворювання не контролюється або погано контролюється, можуть бути сприйнятливішими до інфекцій, оскільки гіперглікемія може знижувати імунітет.

Контроль рівня глюкози є ключовим чинником у зв'язку з тим, що хороший контроль глікемії може сприяти зниженню ризику і тяжкості інфекції. В ADA повідомили, що в Китаї люди з ЦД мають вищі показники серйозних ускладнень і смертності, ніж люди з вірусом без ЦД. Однак є кілька способів знизити цей ризик. Згідно з рекомендаціями $\mathrm{ADA}$, «якщо ЦД добре лікують, ризик серйозного захворювання від COVID-19 приблизно такий же, як і в населення в цілому».

ЦД, який не лікують належним чином, може збільшити ризик пов'язаних із ним ускладнень, одним з яких може бути серцева недостатність - ще один стан, який вказаний Всесвітньою організацією охорони здоров'я та Центрів із контролю і профілактики захворювань, як такий, що створює вищий ризик серйозних ускладнень від COVID-19.

ADA постулює, що вірусні інфекції, такі як новий коронавірус, підсилюють запалення, яке також маніфестує, коли рівень глюкози в крові перевищує цільовий показник, що ще більше підвищує ризик виникнення ускладнень. Ожиріння є основним чинником ризику ЦД i, мабуть, незалежним чинником ризику важкого захворювання при COVID-19. Таким чином, частота важких захворювань, ймовірно, буде особливо високою в регіонах і серед 
COVID-19

населення, де поширені як ожиріння, так і діабет.

Оскільки важча гіперглікемія супроводжує прогресування до важкого легеневого і системного захворювань, кращий метаболічний контроль досягається при використанні інсуліну або інших засобів. Ускладнення ЦД (зокрема захворювання нирок, серця і периферичних судин) можуть бути додатковими чинниками ризику.

Деякі маркери системного запалення підвищуються у важких випадках, що створює нові потенційні терапевтичні мішені. Особливу зацікавленість викликає спостереження, де експресія АПФ2 пов'язана з ЦД може бути залучена в цю вірусну інфекцію, що зумовлює напрямок для досліджень із розробки цілеспрямованих втручань [120].

Пацієнти з ЦД1 і ЦД2 мають вищий ризик діабетичного кетоацидозу при захворюванні вірусною інфекцією. Якщо пацієнт із ЦД знаходиться в стані діабетичного кетоацидозу, це може ускладнити запобігання сепсису і септичного шоку, які, згідно з ADA, «е одними 3 найсерйозніших ускладнень, з якими стикаються деякі люди з COVID-19». За рекомендаціями ADA, пацієнтам з ЦД і COVID-19, які знаходяться у важкому стані, слід призначати інсулін, а пероральні цукрознижувальні препарати, зокрема метформін та інгібітори SGLT2, слід скасувати [121].

Це стандартна тактика в пацієнтів, що знаходяться в критичному стані. Метформін може підвищувати рівень молочної кислоти, а інгібітори SGLT2 викликають гіповолемію, пригнічують метаболізм жирів і потенціюють ацидоз. У доклінічних дослідженнях метформін продемонстрував протизапальну дію і зниження біомаркерів запалення в людей із ЦД2. Останні дані показали, що використання метформіну значно знижує ймовірність смерті. У людей, які отримували метформін, ризик смерті становив $11 \%$, що був таким же, як і в загальній популяції COVID-19, і значно нижчим у пацієнтів із ЦД, які не отримували метформін (24\% смертності) [72]. Припиняється також введення аналогів ГПП-1, які можуть викликати регургітацію, і піоглітазону, терапія якими супроводжується гіперволемією.

Протизапальні та імуномодулювальні ефекти інгібіторів 3-гідрокси-3-метилглутарил-КоА редуктази або статинів припускають, що вони можуть бути корисні для лікування грипу та бактеріальних інфекцій $[122,123]$. Дослідження, виконане в Китаї, показало, що використання статинів було пов'язано з нижчим ризиком смерті від усіх причин і сприятливим профілем одужання в госпіталізованих пацієнтів із COVID-19 [124].

Нині терапія статинами активно застосовується в пацієнтів із ЦД на тлі коронавірусної інфекції. В останніх дослідженнях статини показані як незалежний захисний чинник виживання [125].

Є дані, які свідчать, що COVID-19 значно збільшує ймовірність тромбоемболічних подій і є переважною причиною смерті [126128]. Перші свідчення аномальних параметрів коагуляції, пов’язаних із COVID-19, з'явилися в ранніх звітах із Китаю. Наприклад, вихідні характеристики перших 99 пацієнтів, госпіталізованих в Ухані, показали, що 6\% мали підвищений час згортання крові, 5\% - підвищений рівень протромбіну і 36\% - підвищений рівень D-димеру [124]. Інше дослідження, виконане в Китаї, показало, що в пацієнтів, які померли від COVID-19, рівень D-димеру і продуктів розпаду фібрину був статистично значуще підвищеним [129]. У дослідженні, в якому брали участь китайські пацієнти середнього віку з COVID-19, понад 71\% померлих відповідали критеріям синдрому внутрішньосудинного згортання крові. Слід зазначити, що нині 11 досліджень виявили високі показники венозної тромбоемболії в пацієнтів із діагнозом COVID-19 [130].

Коагулопатія, пов'язана з COVID-19, змінюється від помірних змін результатів лабораторних досліджень до дисемінованого внутрішньосудинного згортання крові з переважним фенотипом тромботичної та/або поліорганної недостатності [131]. Глибока запальна реакція у зв'язку з інфекцією SARS$\mathrm{CoV}-2$ призводить до розвитку синдрому дисемінованого внутрішньосудинного згортання крові [128]. Дисфункція ендотелію судин робить свій внесок у патофізіологію мікроциркуляторних змін у пацієнтів з інфекцією SARSCoV-2 [132].

Важливо відзначити, що SARS-CoV-2 може проникати в ендотеліальні клітини та інфікувати їх через рецептор АПФ2, при цьому 
реплікація вірусу викликає інфільтрацію запальних клітин, апоптоз ендотеліальних клітин і протромботичні ефекти мікросудин [133, 134]. Патологоанатомічні дослідження пацієнтів, які померли від інфекції SARS-CoV-2, показали наявність вірусних включень в ендотеліальних клітинах і секвестрованих інфільтрацією мононуклеарних і поліморфноядерних клітин із доказами апоптозу ендотелію [134].

Таким чином, дані свідчать про те, що підвищене вивільнення чинників згортання крові та порушення регуляції та руйнування ендотеліальних клітин є основними механізмами збільшення тромбоемболії в пацієнтів із COVID-19 [135]. Ендотеліальна дисфункція може також пояснювати повідомлення про цереброваскулярні ускладнення в молодших пацієнтів і в пацієнтів з ішемією міокарда i/ або тромбоемболічними ускладненнями [134, 136].

У декількох публікаціях повідомляється про підвищений ризик тромбоемболії в пацієнтів із ЦД за межами конкретної ситуації з інфекцією SARS-CoV-2. Наприклад, в одному з популяційних досліджень показано, що пацієнти з ЦД2 мають підвищений ризик венозної тромбоемболії порівняно з контрольною групою (ОР 1,44, 95\% ДІ 1,27-1,63) [137]. Крім того, ризик тромбоемболії легеневої артерії був вищим у пацієнтів із ЦД2, ніж у пацієнтів контрольної групи (ОР 1,52, 95\% ДI 1,22-1,90).

В іншому дослідженні показано, що частота тромбозу глибоких вен після повної заміни колінного суглоба була статистично вірогідно вищою в пацієнтів із ЦД, ніж у пацієнтів без нього [138]. Також було виявлено, що Цд пов'язаний зі збільшенням більш ніж у два рази ризику утворення виразок після тромбозу глибоких вен [139, 140]. Таким чином, пацієнти з ЦД вже належать до категорії високого ризику тромбоемболічної події або інсульту [141].

Точні молекулярні та клітинні механізми, що лежать в основі підвищеного згортання крові в пацієнтів із COVID-19, наразі недостатньо вивчені, а звичайна профілактика не завжди ефективна для запобігання тромбоемболії [142]. Однак антикоагулянтна терапія низькомолекулярним гепарином дає кращі прогнози в пацієнтів із важкою формою
COVID-19 із великим ризиком тромбоемболії, наприклад, у пацієнтів із підвищеним рівнем D-димеру [143]. Таким чином, необхідно починати антикоагулянтну терапію в госпіталізованих пацієнтів із COVID-19 від помірного до тяжкого ступеня захворювання.

Хоча докази, що підтверджують будьякий прямий вплив аналогів ГПП-1 на ризик тромбоемболії обмежені, кілька досліджень на тваринах показали, що лікування аналогами ГПП-1 пригнічує утворення атероми та стабілізує бляшки в сонних артеріях і дугах аорти [144, 145]. Фактично, гліптини можуть зберігати ендотеліальну функцію завдяки своєму протизапальному, антиоксидантному і потенційно захисному впливу на судинну систему, що є корисними аспектами в боротьбі з COVID-19 [125]. Введення ГПП-1 in vitro знижує експресію матриксних металопротеїназ 2 та білка хемотаксиса моноцитів (Monocyte chemoattractant protein 1, MCP1) i транслокацію NF-кB-p65, що пов'язано 3 високим ризиком тромбоемболії [144]. Дослідження серцево-судинних наслідків показало, що терапія дулаглутидом (аналогом ГПП-1 тривалої дії) знижує частоту інсульту в пацієнтів із ЦД2 [146].

Таким чином, пацієнтам із ЦД необхідно вибирати протидіабетичні засоби, що знижують ризик тромбоемболічних подій. Зараз проводяться численні клінічні випробування для оцінки безпеки та ефективності можливих препаратів, включаючи ремдесивір, тоцилізумаб, лопінавір/ритонавір, рибавірин, інтерферон, хлорохінін та інші, які досить широко використовуються в усіх країнах із початку пандемії [147]. Хоча для жодного 3 препаратів немає надійних доказів специфічної противірусної ефективності або клінічних результатів щодо лікування COVID-19, деякі препарати використовуються на підставі обмежених клінічних даних або проходять клінічні випробування. Проблеми безпеки препаратів повинні бути співставлені з їхньою відносною користю. Зараз є певні проблеми щодо деяких із цих препаратів, які застосовуються в пацієнтів із ЦД.

\section{Лікування COVID-19 у хворих на ЦД}

Глобальна пандемія COVID-19 зумовила пошук ефективних засобів профілактики та лікування інфекції SARS-CoV-2 [131]. Наразі тривають численні клінічні випробування, 
COVID-19

спрямовані на вивчення імунної відповіді на інфекцію. Однак ефективність більшості ліків ще не доведена. Синдром вивільнення цитокінів - «цитокіновий шторм» - вважається центральним у патогенезі швидкого погіршення і стрімкого наростання поліорганної дисфункції в пацієнтів із COVID-19. Отже, імуномодулювальні агенти постулюються як вельми ефективні.

Одним із фармакологічних варіантів, який актуальний для пацієнтів із ЦД, є хлорохін/ гідроксихлорохін. Широко використовуваний для лікування малярії та автоімунних захворювань хлорохін також вважається противірусним препаратом широкого спектра дії. Деякі автори повідомляли, що гідроксихлорохін покращує глікемічний контроль у декомпенсованих, резистентних до базової антидіабетичної терапії, пацієнтів із ЦД [148]. Гіпоглікемія є відомим несприятливим ефектом (впливом) терапії гідроксихлорохіном.

Встановлено такі механізми антигіперглікемічної активності хлорохіну/гідроксихлорохіну: зниження внутрішньоклітинної деградації інсуліну, збільшення опосередкованого інсуліном транспорту глюкози й секреції інсуліну, а також підвищення чутливості до інсуліну [148]. Отже, на думку деяких дослідників, слід дотримуватися особливої обережності при одночасному використанні цих препаратів 3 іншими засобами, які знижують рівень глюкози, що може спричинити необхідність зменшення дози препаратів [149].

Імунодепресанти, схвалені для терапії автоімунних захворювань, включаючи тяжкий ревматоїдний артрит - тоцилізумаб, або актерм, спрямовані на придушення гіперсекреції інтерлейкіну-6, який є однією з ланок патофізіологічного циклу цитокінового шторму в пацієнтів із COVID-19 на тлі діабету.

Системні кортикостероїди, як відомо, викликають гіперглікемію, перш за все, внаслідок підвищення постпрандіальних рівнів глюкози, інсулінорезистентності та дисфункції $\beta$-клітин ПШЗ, що часто вимагає початку інсулінової терапії [150]. Всупереч цій проблемі, внутрішньовенна терапія дексаметазоном статистично значуще збільшувала кількість днів без ШВЛ у пацієнтів із важким ГРДС i COVID-19 [151, 152]. Крім того, в метааналізі з клінічних випробувань показано, що системна терапія кортикостероїдами пов’язана зі зниженням короткострокової смертності від усіх причин у пацієнтів із важкою формою COVID-19 [153]. Лікування гідрокортизоном у стаціонарі за різними схемами також показало тенденцію до кращого результату [154].

Однак інше дослідження не змогло довести жодного позитивного ефекту низьких доз гідрокортизону при лікуванні пацієнтів із COVID-19 [155]. Причиною таких результатів, що розчаровують, може бути доза, менша, ніж оптимальна. Необхідні подальші дослідження для з'ясування впливу фармакологічного лікування COVID-19 на метаболізм глюкози в пацієнтів із ЦД.

Тяжке пошкодження легеневої тканини 3 подальшою маніфестацією ГРДС частково зумовлено потужною імунною відповіддю. Хоча кортикостероїди пригнічують запалення легенів, вони також одночасно пригнічують імунітет [156]. 3 огляду на системний гіперглікемічний ефект і серйозний вплив цих препаратів на імунну відповідь [157], слід дотримуватися особливої обережності в пацієнтів із ЦД. Нині кортикостероїди широко використовуються при лікуванні важкого ГРДС, викликаного вірусною пневмонією, і зарекомендували себе як препарати вибору для пацієнтів, які перебувають у важкому стані [158]. Оскільки при застосуванні даних препаратів у пацієнтів із ЦД може наростати гіперглікемія, може виникнути необхідність в ескалації інсулінової терапії [149].

Загальна мета застосування противірусних препаратів полягає в тому, щоб зупинити реплікацію нової вірусної РНК, котрі дають можливості інфікованим клітинам пацієнтів iз COVID-19 стати «виробничими майданчиками» для дублювання нових віріонів. Аналоги нуклеотидів здійснюють це шляхом включення основи в реплікувальний ланцюг, від якої вірусна РНК-полімераза не може ефективно здійснювати дублювання. На сьогодні івермектин - протипаразитарний препарат, який рекомендований до досить широкого застосування, продемонстрував противірусну активність щодо SARS-COV-2. Його раннє призначення може знижувати вірусне навантаження, зменшувати тяжкість захворювання і ризик подальшого розповсюдження інфекції [159, 160]. 
Препарат ремдесивір спочатку випробовувався у хворих на лихоманку Ебола. Раніше Управління з санітарного нагляду за якістю харчових продуктів та медикаментів США (Food and Drug Administration, FDA, USFDA) схвалило його використання для пацієнтів із вкрай важким перебігом COVID-19. Ремдесивір, інгібітор нуклеотидного аналога РНКзалежної РНК-полімерази, підвищував глікемію і збільшував інсулінорезистентність у мишей, які отримували дієту з високим вмістом жирів [160]. Навпаки, підвищення рівня глюкози в крові було однаковим між групами, які отримували ремдесивір, і групами, які отримували плацебо, у двох рандомізованих клінічних дослідженнях із мультиетнічними групами та пацієнтами з Китаю [161163]. Таким чином, потрібні додаткові докази, щоб з'ясувати його вплив на метаболізм глюкози.

Зараз 5 клінічних випробувань в Китаї та США оцінюють, чи може ремдесивір зменшити ризик ускладнень або скоротити терміни перебігу захворювання в пацієнтів із COVID-19. На цей момент FDA дозволила використання ремдесивіру, який, хоча і не впливає на зниження летальності, однак значно скорочує терміни перебігу захворювання в пацієнтів із менш тяжкими формами патології [164]. Наразі проводяться подальші дослідження для оцінки ефективності ремдесивіру в пацієнтів із COVID-19 і ЦД, а також у пацієнтів із мультиморбідністю.

Противірусні препарати - інгібітори протеази перешкоджають утворенню нових віріонів інфікованими клітинами, зв’язуючи та інактивуючи вірусні протеази, щоб зупинити реплікацію вірусу. Скринінгове дослідження продемонструвало, що лікування лопінавіром-ритонавіром (Abbvie) і рибавірином знижує смертність і ГРДС порівняно з терапією тільки одним рибавірином [165]. Ритонавір додають до лопінавіру як фармакокінетичний підсилювач [166]. Цей препарат є потужним інгібітором цитохрому CYP 3А4, ферменту, який інактивує лопінавір. Повідомлялося, що інгібітори протеази, лопінавір і ритонавір, збільшують ризик виникнення гіперглікемії та дебюту вперше виявленого ЦД, викликають декомпенсацію наявного ЦД і розвиток діабетичного кетоацидозу [167-170].
Ще одна проблема, пов’язана з інгібіторами протеази, - це фармакологічна взаємодія з цукрознижувальними препаратами, які вводять спільно. Пацієнтам, які застосовують ці комбінації препаратів, рекомендується частий моніторинг рівня глюкози в крові і корегування дозування. Зараз клінічні дослідження ефективності препаратів у хворих із коронавірусною інфекцією тривають [171].

Створення вакцини має на меті створення довготривалого імунітету. Наразі проводяться випробування нових препаратів для оцінки безпеки та імунної відповіді. На відміну від ДНК-вакцин, вакцини мРНК можуть інтегруватися в геном господаря, знижуючи ризик мутацій [172].

Вакцина мРНК-1273 являє собою нову інкапсульовану в ліпідну наночастинку на основі мРНК, яка кодує стабілізовану перед префузією форму білка шипа [173]. Префузійна форма ідентифікується як просторова конформація білка шипа, перш ніж він вступить у зв’язок з АПФ2. Антитіла проти префузійної форми можуть запобігати проникненню вірусу, а також зменшувати поширення віріонів.

Макролідний антибіотик азитроміцин, який використовується для інгібіції синтезу бактеріального білка шляхом зв’язування з субодиницею бактеріальної рибосоми, також використовується для лікування загострень хронічних обструктивних хвороб легенів і реактивних захворювань дихальних шляхів. Це друге використання може зображати модулювальну дію азитроміцину на імунні клітини. Він зменшуе вивільнення респіраторно-синцитіального вірусу за рахунок зменшення передачі сигналів інтерферону in vivo та уповільнює вивільнення прозапальних цитокінів у гладеньких м'язах дихальних шляхів та епітеліальних клітинах [174]

У проспективному дослідженні, виконаному у Франції за участю 22 пацієнтів, відзначено, що комбінація 600 мг гідроксихлорохіну й азитроміцину (500 мг у перший день і потім 250 мг щодня протягом наступних 4 днів) знижувала вірусне навантаження ефективніше, ніж один гідроксихлорохін [175]. Основною побічною дією азитроміцину є пролонгація інтервалу QT, що призводить до порушень серцевого ритму [176].

В одному когортному дослідженні 5-денний курс азитроміцину призводив до майже триразового збільшення смертності через 
COVID-19

серцево-судинні ускладнення порівняно 3 клінічними дослідженнями інших видів антибіотиків [177], хоча в наступному когортному дослідженні [178] і метааналізі проспективних рандомізованих контрольованих досліджень не виявили підвищеного ризику смерті [179].

Раніше висловлювалися побоювання, що інгібітори РААС можуть підвищувати сприйнятливість до SARS-CoV-2 [30]. Інфекція SARS-CoV-2 викликає активацію PAAC, яка може призвести до «цитокінового шторму» через вісь AngII. У суб'єктів із вже наявним ЦД, інфікованих SARS-CoV-2, важкий перебіг захворювання пов'язаний із попереднім прозапальним статусом та ендотеліальною дисфункцією, а також частотою супутніх захворювань, таких як ожиріння, артеріальна гіпертензія, СС3, неалкогольна жирова хвороба печінки та хронічна хвороба нирок, а також із неконтрольованою гіперглікемією, що викликає підвищення тяжкості захворювання, збільшення кількості госпіталізацій у відділення інтенсивної терапії та може бути причиною поганого прогнозу й вищих показників смертності в пацієнтів із ЦД [171].

Терапія з використанням відповідних цукрознижувальних засобів та правильне регулювання рівня глюкози в крові сприяє одужанню і виживанню пацієнтів із ЦД і COVID-19. Різні аспекти, такі як переваги, протипоказання й обмеження використання певних комбінацій цукрознижувальних засобів і противірусних препаратів, які можуть вплинути на результат захворювання в пацієнтів із ЦД і COVID-19, повинні бути ретельно проаналізовані.

На сьогодні одним із перспективних напрямків у придушенні коронавірусної інфекції також вважається введення більш розчинних форм АПФ2. У дослідженнях на мишах продемонстровано, що COVID-19 пригнічує білок АПФ2, зв'язуючи його спайк-протеїн, що сприяє важкому пошкодженню легенів [180]. Це свідчить, що надлишок АПФ2 може конкурентно зв'язуватися з COVID-19 не тільки для нейтралізації вірусу, але і для збереження клітинної активності АПФ2, яка негативно регулює ренін-ангіотензинову систему, захищаючи легені від пошкодження.

Таким чином, лікування розчинною формою АПФ2 може виконувати подвійну роль: уповільнення проникнення вірусу в клітини й захист легенів від пошкодження. Нарешті, як демонструють недавні дослідження, альвеолярні клітини, інфіковані коронавірусом, експресують на своїй поверхні менше АПФ2, ніж нормальні клітини in vitro.

Під час пандемії COVID-19 в літературі активно тривають дискусії щодо переваг або шкоди, пов'язаних із використанням інгібіторів АПФ або блокаторів рецепторів ангіотензину. Крім класичного РААС, альтернативні компоненти, включаючи АПФ2, Ang (1-7), Ang (1-9) і рецептор Mas, можуть бути долучені до проникнення й прогресування SARS-CoV-2. Багато міжнародних медичних спільнот рекомендують продовжувати приймати інгібітори РААС, тому що немає доведених доказів їхньої шкоди при їх використанні в контексті ЦД i COVID-19.

Раніше багатьма дослідниками висувалася гіпотеза, що застосування іАПФ і БРА підвищує схильність до COVID-19, і висловлювалася гіпотеза блокади рецепторів АПФ2 або запобігання зв'язування з ними COVID-19 за допомогою інших засобів як інноваційного підходу, який можна було б використовувати для створення нового препарату для зниження смертності серед людей, уражених вірусом.

Іншими авторами висувається припущення, що СС3, а не імунодефіцит, є найважливішими чинниками ризику COVID-19. Пацієнти з ССЗ, мабуть, мають більший ризик розвитку інфекції COVID-19. Одна з можливих причин може бути наступною: пацієнти 3 супутніми захворюваннями, такими як артеріальна гіпертензія, ЦД2, патологія серця і нирок, можуть мати показання до застосування іАПФ і БРА.

Чи можливий зв'язок між цими спостереженнями? Чи підвищується експресія рецепторів АПФ2 в клітинах-мішенях вірусу внаслідок використання іАПФ та БРА і, отже, чи вищий ризик важкого перебігу в людини? Нині твердо встановлено, що застосування інгібіторів РАAC має потужну захисну дію на тканину легенів [181].

Наразі немає даних про оптимальне лікування пацієнтів із ЦД, інфікованих SARS-CoV-2, а також пацієнтів із COVID-19, в яких розвивається глікемічна декомпенсація. Жоден із представлених препаратів не виявився домінантним у лікувальній стратегії для терапіï COVID-19 i, наразі, терапевтичний прорив 
досягнуто тільки при використанні дексаметазону. Ретельний моніторинг рівня глюкози та аналіз взаємодії лікарських засобів можуть сприяти поліпшенню клінічної симптоматики й зниженню ризиків несприятливих наслідків. Індивідуальні терапевтичні стратегії та оптимальні цілі контролю глюкози повинні бути сформульовані на підставі тяжкості захворювання, наявності супутніх захворювань і ускладнень, пов'язаних із ЦД, з урахуванням віку пацієнтів та наявності інших обтяжливих чинників.

Доведено, що коронавірусна інфекція має великий вплив на лікування ЦД, тому що посилює запалення і змінює реакцію імунної системи, що призводить до складнощів у контролі глікеміі. Інфекція SARS-CoV-2 також збільшує ризик тромбоемболії та з більшою ймовірністю викликає кардіореспіраторну недостатність у пацієнтів із ЦД порівняно з пацієнтами без нього. Зараз вважається, що всі ці механізми сприяють поганому прогнозу в пацієнтів із ЦД i COVID-19.

Під час пандеміі COVID-19 суворий глікемічний контроль і управління чинниками ризику ССЗ мають вирішальне значення для пацієнтів із ЦД. Ліки, які застосовують як при ЦД, так і при серцево-судинних захворюваннях, слід відповідно скоригувати для людей із високим ризиком зараження SARS-CoV-2 [182-184]. Грунтуючись на даних результатах, комбіноване лікування цими двома агентами може бути кориснішим, ніж будь-яким 3 них окремо. Однак слід мати на увазі, що ефективність дексаметазону в лікуванні COVID-19 була доведена в добре спланованих рандомізованих клінічних дослідженнях, таких як «Рандомізована оцінка терапії Covid-19» (Randomised Evaluation of Covid-19 Therapy, RECOVERY), тоді як таких переконливих досліджень для гідроксихлорохіну не виконувалося [182].

Глобальна пандемія COVID-19, безперечно, становить значну небезпеку для здоров'я людей, особливо для пацієнтів із ЦД. Специфічна терапія знаходиться на стадії створення, на відміну від вакцини від COVID-19. Оптимальна стратегія ведення таких пацієнтів, наприклад, підбір цукрознижувальних, антигіпертензивних i гіполіпідемічних препаратів, є важливою проблемою для сучасних і майбутніх досліджень. ЦД і інші супутні захворювання є важливими предикторами важкого перебігу і високої смертності в пацієнтів із COVID-19 [185].

Нині необхідні подальші клінічні дослідження, щоб забезпечити краще розуміння патофізіологічних механізмів, що лежать в основі зв’язку між COVID-19 і ЦД, для здійснення ефективного терапевтичного прориву як у лікувальних стратегіях, так і в медикаментозних тактиках, націлених на запобігання коронавірусної інфекції в пацієнтів із ЦД.

\section{Список використаної літератури}

1. Huang C, Wang Y, Li X, Ren L, Zhao J, Hu Y, et al. Clinical features of patients infected with 2019 novel coronavirus in Wuhan, China. Lancet. 2020 Feb 15;395(10223):497-506.

2. Rothan HA, Byrareddy SN. The epidemiology and pathogenesis of coronavirus disease (COVID-19) outbreak. J Autoimmun. 2020;109:102433.

3. Ugwueze CV, Ezeokpo BC, Nnolim BI, Agim EA, Anikpo NC Onyekachi KE. COVID-19 and diabetes mellitus: the link and clinical implications. Dubai Diabetes Endocrinol J. 2020;26:69-77.

4. Chan-Yeung M, Xu RH. SARS: epidemiology. Respirology. 2003 Nov;8 Suppl(Suppl 1): S9-14.

5. Song Z, Xu Y, Bao L, Zhang L, Yu P, Qu Y, et al. From SARS to MERS, Thrusting coronaviruses into the spotlight. Viruses. 2019 Jan 14;11(1), pii: E59.

6. Poutanen SM. Etiologic agents of infectious diseases. In: Long S, Pickering L, Prober C, editors. Principles and practice of paediatric infectious diseases. 4th ed. Elsevier; 2012. p. 1547-712.

7. European Centre for Disease Prevention and Control COVID-19 situation update worldwide. Available from: https:// www.ecdc.europa.eu/en/geographical-distribution-2019-ncovcases [Accessed 31st May 2021].

8. Chan JC, Lim LL, Wareham NJ, Shaw JE, Orchard TJ, Zhang P, et al. The lancet commission on diabetes: using data to transform diabetes care and patient lives. Lancet. 2021 Dec 19;396(10267):2019-82.

9. Parohan M, Yaghoubi S, Seraji A, Javanbakht MH, Sarraf P, Djalali M. Risk factors for mortality in patients with Coronavirus disease 2019 (COVID-19) infection: a systematic review and metaanalysis of observational studies. Aging Male. 2020 Dec;23(5):1416-24.

10. Hafidh K, Abbas S, Khan A, Kazmi T, Nazir Z, Aldaham T. The clinical characteristics and outcomes of COVID-19 infections in patients with diabetes at a tertiary care center in the UAE. Dubai Diabetes Endocrinol J. 2021;26(4):1-6.

11. Li G, Chen Z, Lv Z, Li H, Chang D, Lu J. Diabetes mellitus and COVID-19: associations and possible mechanisms. Int J Endocrinol. 2021 Apr 1;2021:7394378.

12. $\mathrm{Wu} \mathrm{Z}$, McGoogan JM. Characteristics of and important lessons from the coronavirus disease 2019 (COVID-19) outbreak in China: summary of a report of 72314 cases from the Chinese Center for Disease Control and Prevention. JAMA. 2020 Apr;323(13):1239-42.

13. Guan W, Ni Z, Hu Yu, Liang W, Ou C, He J, et al. Clinical characteristics of coronavirus disease 2019 in China. N Engl J Med. 2020 Apr 30;382(18):1708-20.

14. Zhou F, Yu T, Du R, Fan G, Liu Y, Liu Z, et al. Clinical course and risk factors for mortality of adult inpatients with COVID-19 in Wuhan, China: a retrospective cohort study. Lancet. $2020 \mathrm{Mar}$ 28;395(10229):1054-62.

15. Yang J, Zheng Y, Gou X, Pu K, Chen Z, Guo Q, et al. Prevalence of comorbidities and its effects in patients infected with SARSCoV-2: a systematic review and meta-analysis. Int J Infect Dis. 2020 May;94:91-5.

16. Bode B, Garrett V, Messler J, McFarland R, Crowe J, Booth R, et al. Glycemic characteristics and clinical outcomes of 
COVID-19

COVID-19 patients hospitalized in the United States. J Diabetes Sci Technol. 2020 Jul;14(4):813-21.

17. Zhu L, She ZG, Cheng X, Oin JJ, Zhang XJ, Cai J, et al. Association of blood glucose control and outcomes in patients with COVID-19 and pre-existing type 2 diabetes. Cell Metab. 2020 Jun 2;31(6):1068-77.e3

18. Al Hayek AA, Robert AA, Matar AB, Algarni A, Alkubedan H, Alharbi $\mathrm{T}$, et al. Risk factors for hospital admission among COVID-19 patients with diabetes. A study from Saudi Arabia. Saudi Med J. 2020 Oct;41(10):1090-7.

19. Zhu Z, Mao Y, Chen G. Predictive value of HbA1C for adverse prognosis in COVID-19: a systematic review and meta-analysis. (January 1, 2021). Available at SSRN: https:// ssrn.com/abstract $=3758344$

20. Sur J, Sharma J, Sharma D. Diabetes might augment the severity of COVID-19: a current prospects. Front Cardiovasc Med. 2021 Jan 5;7:613255.

21. Yang P, Feng J, Peng Q, Liu X, Fan Z. Advanced glycation end products: potential mechanism and therapeutic target in cardiovascular complications under diabetes. Oxid Med Cell Longev. 2019 Dec 6;2019:9570616.

22. Onder G, Rezza G, Brusaferro S. Case-fatality rate and characteristics of patients dying in relation to COVID-19 in Italy. JAMA. 2020 Mar 23;323(18):1775-6.

23. Corona G, Pizzocaro A, Vena W, Rastrelli G, Semeraro F, Isidori AM, et al. Diabetes is most important cause for mortality in COVID-19 hospitalized patients: Systematic review and metaanalysis. Rev Endocr Metab Disord. 2021 Jun;22(2):275-96.

24. Knapp S. Diabetes and infection: is there a link? - A mini-review. Gerontology. 2013; 59(2):99-104.

25. Geerlings SE, Hoepelman AI. Immune dysfunction in patients with diabetes mellitus (DM). FEMS Immunol Med Microbiol. 1999 Dec;26(3-4):259-65.

26. Petrie JR, Guzik TJ, Touyz RM. Diabetes, hypertension, and cardiovascular disease: clinical insights and vascular mechanisms. Can J Cardiol. 2018 May;34(5):575-84.

27. López-Collazo E, Avendaño-Ortiz J, Martín-Quirós A, Aguirre LA Immune response and COVID-19: A mirror image of sepsis. Int J Biol Sci. 2020;16(14):2479-89

28. Muniyappa R, Gubbi S. COVID-19 pandemic, coronaviruses, and diabetes mellitus. Am J Physiol Endocrinol Metab. 2020 May 1;318(5): E736-41.

29. Li XC, Zhang J, Zhuo JL. The vasoprotective axes of the reninangiotensin system: physiological relevance and therapeutic implications in cardiovascular, hypertensive and kidney diseases. Pharmacol Res. 2017 Nov;125(Pt A):21-38.

30. Gheblawi M, Wang K, Viveiros A, Nguyen Q, ZhongJC, Turner AJ, et al. Angiotensin-converting enzyme 2: SARS-CoV-2 receptor and regulator of the renin-angiotensin system. Celebrating the 20th anniversary of the discovery of ACE2. 2020;126:1456-74.

31. Yang JK, Lin SS, Ji XJ, Guo LM. Binding of SARS coronavirus to its receptor damages islets and causes acute diabetes. Acta Diabetol. 2010 Sep;47(3):193-9.

32. Hamming I, Timens W, Bulthuis ML, Lely AT, Navis G, van Goor H. Tissue distribution of ACE2 protein, the functional receptor for SARS coronavirus. A first step in understanding SARS pathogenesis. J Pathol. 2004 Jun;203(2):631-7.

33. Gurwitz D. Angiotensin receptor blockers as tentative SARSCoV-2 therapeutics. Drug Dev Res. 2020 Aug;81(5):537-40.

34. Hussain A, Bhowmik B, do Vale Moreira NC. COVID-19 and diabetes: Knowledge in progress. Diabetes Res Clin Pract. 2020 Apr;162:108142.

35. Benter IF, Yousif MH, Dhaunsi GS, Kaur J, Chappell MC, Diz DI Angiotensin-(1-7) prevents activation of NADPH oxidase and renal vascular dysfunction in diabetic hypertensive rats. Am J Nephrol. 2008;28(1):25-33

36. El-Hashim AZ, Renno WM, Raghupathy R, Abduo HT, Akhtar S Benter IF. Angiotensin-(1-7) inhibits allergic inflammation, via the MAS1 receptor, through suppression of ERK1/2- and NF- $\mathrm{KB}$ dependent pathways. Br J Pharmacol. 2012 Jul;166(6):1964-76.

37. Santos RA. Angiotensin-(1-7). Hypertension. 2014 Jun;63(6): 1138-47.

38. Santos RA, Simoes e Silva AC, Maric C, Silva DM, Machado RP, de Buhr I, et al. Angiotensin-(1-7) is an endogenous ligand for the
G proteincoupled receptor Mas. Proc Natl Acad Sci USA $2003 \mathrm{Jul}$ 8;100(14):8258-63.

39. Chamsi-Pasha MA, Shao Z, Tang WH. Angiotensin-converting enzyme 2 as a therapeutic target for heart failure. Curr Heart Fail Rep. 2014 Mar;11(1):58-63.

40. Anguiano L, Riera M, Pascual J, Valdivielso JM, Barrios C, Betriu A, et al. Circulating angiotensin-converting enzyme 2 activity in patients with chronic kidney disease without previous history of cardiovascular disease. Nephrol Dial Transplant. $2015 \mathrm{Jul} ; 30(7): 1176-85$.

41. Wang G, Lai FM, Kwan BC, Lai KB, Chow KM, Li PK, et al. Expression of ACE and ACE2 in patients with hypertensive nephrosclerosis. Kidney Blood Press Res. 2011;34(3):141-9.

42. Gilbert A, Liu J, Cheng G, An C, Deo K, Gorret AM, et al. A review of urinary angiotensin converting enzyme 2 in diabetes and diabetic nephropathy. Biochem Med (Zagreb). 2019 Feb 15;29(1):010501.

43. Leung JM, Yang CX, Tam A, Shaipanich T, Hackett TL Singhera GK, et al. ACE-2 expression in the small airway epithelia of smokers and COPD patients: implications for COVID-19. Eur Respir J. 2020 May 14;55(5):2000688.

44. Agarwal S, Agarwal SK. Endocrine changes in SARS-CoV-2 patients and lessons from SARS-CoV. Postgrad Med J. 2020 Jul;96(1137):412-6.

45. AlGhatrif M, Cingolani O, Lakatta EG. The dilemma of coronavirus disease 2019, aging, and cardiovascular disease: Insights from cardiovascular aging science. JAMA Cardiol. $2020 \mathrm{Jul} \mathrm{1;5(7):747-8.}$

46. Kiely DG, Cargill RI, Wheeldon NM, Coutie WJ, Lipworth BJ Haemodynamic and endocrine effects of type 1 angiotensin II receptor blockade in patients with hypoxaemic cor pulmonale. Cardiovasc Res. 1997 Jan;33(1):201-8.

47. Kuba K, Imai Y, Rao S, Gao H, Guo F, Guan B, et al. A crucial role of angiotensin converting enzyme 2 (ACE2) in SARS coronavirusinduced lung injury. Nat Med. 2005 Aug;11(8):875-9.

48. Imai Y, Kuba K, Rao S, Huan Y, Guo F, Guan B, et al. Angiotensinconverting enzyme 2 protects from severe acute lung failure. Nature. 2005 Jul 7;436(7047):112-6.

49. Peng YD, Meng K, Guan HQ, Leng L, Zhu RR, Wang BY, et al. Clinical characteristics and outcomes of 112 cardiovascular disease patients infected by 2019-nCoV. Zhonghua Xin Xue Guan Bing Za Zhi. 2020 Mar 2;48(0): E004.

50. Qiao W, Wang C, Chen B, Zhang F, Liu Y, Lu Q, et al. Ibuprofen attenuates cardiac fibrosis in streptozotocin-induced diabetic rats. Cardiology. 2015;131(2):97-106.

51. Fang L, Karakiulakis G, Roth M. Are patients with hypertension and diabetes mellitus at increased risk for COVID-19 infection? Lancet Respir Med. 2020 Apr; 8(4): e21.

52. Fadini GP, Morieri ML, Longato E, Avogaro A. Prevalence and impact of diabetes among people infected with SARS-CoV-2. J Endocrinol Invest. 2020 Jun;43(6):867-9.

53. Longato E, Di Camillo B, Sparacino G, Saccavini C, Avogaro A, Fadini GP. Diabetes diagnosis from administrative claims and estimation of the true prevalence of diabetes among 4.2 million individuals of the Veneto region (North East Italy). Nutr Metab Cardiovasc Dis. 2020 Jan 3;30(1):84-91.

54. Ceccarelli M, Berretta M, Venanzi Rullo E, Nunnari G, Cacopardo B. Differences and similarities between Severe Acute Respiratory Syndrome (SARS)-CoronaVirus (CoV) and SARSCoV-2. Would a rose by another name smell as sweet? Eur Rev Med Pharmacol Sci. 2020 Mar;24(5):2781-3.

55. Nieto-Fontarigo JJ, González-Barcala FJ, San José E, Arias P, Nogueira M, Salgado FJ. CD26 and asthma: a comprehensive review. Clin Rev Allergy Immunol. 2019 Apr;56(2):139-60.

56. Iacobellis G. COVID-19 and diabetes: Can DPP4 inhibition play a role? Diabetes Res Clin Pract. 2020 Apr;162:108125.

57. Anderluh M, Kocic G, Tomovic K, Kocic H, Smelcerovic A. DPP-4 inhibition: A novel therapeutic approach to the treatment of pulmonary hypertension? Pharmacol Ther. 2019 Sep;201:1-7.

58. Drucker DJ. Insufficient evidence' to recommend DPP-IV inhibitor treatment in type 2 diabetes with COVID-19. Available from: https://www.healio.com/news/endocrinology/20200420/ insufficient-evidence-to-recommend-dppiv-inhibitor-treatmentin-type-2-diabetes-with-covid19. [Accessed 31st May 2021]. 
59. Sun B, Huang S, Zhou J. Perspectives of antidiabetic drugs in diabetes with coronavirus infections. Front Pharmacol. 2021 Jan 29;11:592439.

60. Smelcerovic A, Kocic G, Gajic M, Tomovic K, Djordjevic V, Stankovic-Djordjevic D, et al. DPP-4 inhibitors in the prevention/treatment of pulmonary fibrosis, heart and kidney injury caused by COVID-19 - a therapeutic approach of choice in type 2 diabetic patients? Front. Pharmacol. 2020 Aug 5;11:1185.

61. Chen Y, Yang D, Cheng B, Chen J, Peng A, Yang C, et al. Clinical characteristics and outcomes of patients with diabetes and COVID-19 in association with glucose-lowering medication. Diabetes Care. 2020 May; dc200660.

62. Viswanathan V, Puvvula A, Jamthikar AD, Saba L, Johri AM Kotsis V, et al. Bidirectional link between diabetes mellitus and coronavirus disease 2019 leading to cardiovascular disease: A narrative review. World J Diabetes. 2021 Mar 15;12(3):215-37.

63. Gupta R, Hussain A, Misra A. Diabetes and COVID-19: evidence, current status and unanswered research questions. Eur J Clin Nutr. 2020 Jun;74(6):864-70

64. Klonoff DC, Umpierrez GE. Letter to the Editor: COVID-19 in patients with diabetes: Risk factors that increase morbidity. Metabolism. $2020 \mathrm{Jul} ; 108: 154224$.

65. Ceriello A, Stoian AP, Rizzo M. COVID-19 and diabetes management: What should be considered? Diabetes Res Clin Pract. 2020 May;163:108151.

66. Pal R, Bhadada SK. Should anti-diabetic medications be reconsidered amid COVID-19 pandemic? Diabetes Res Clin Pract. 2020 May;163:108146.

67. Kawanami D, Matoba K, Takeda Y, Nagai Y, Akamine T, Yokota T, et al. SGLT2 inhibitors as a therapeutic option for diabetic nephropathy. Int J Mol Sci. 2017 May 18;18(5):1083.

68. Rod JE, Oviedo-Trespalacios O, Cortes-Ramirez J. A brief-review of the risk factors for covid-19 severity. Rev Saude Publica. 2020;54:60.

69. European Medicines Agency. EMA advises continued use of medicines for hypertension, heart or kidney disease during COVID-19 pandemic. Available from: https://www.ema. europa.eu/en/news/ema-advises-continued-use-medicineshypertension-heart-kidney-disease-during-covid-19pandemic [Accessed 27st May 2021].

70. Prattichizzo F, La Sala L, Rydén L, Marx N, Ferrini M, Valensi P, Ceriello A. Glucose-lowering therapies in patients with type 2 diabetes and cardiovascular diseases. Eur J Prev Cardiol. 2019 Dec;26(2 suppl):73-80

71. Wilding J, Fernando K, Milne N, Evans M, Ali A, Bain S, et al. SGLT2 inhibitors in type 2 diabetes management: key evidence and implications for clinical practice. Diabetes Ther 2018 Oct;9(5):1757-73.

72. Crouse AB, Grimes T, Li P, Might M, Ovalle F, Shalev A. Metformin use is associated with reduced mortality in a diverse population with COVID-19 and diabetes. Front Endocrinol (Lausanne). 2021 Jan 13;11:600439

73. Filardi T, Morano S. COVID-19: is there a link between the course of infection and pharmacological agents in diabetes? J Endocrinol Invest. 2020 Aug;43(8):1053-60.

74. Zhang W, Li C, Liu B, Wu R, Zou N, Xu YZ, et al. Pioglitazone upregulates hepatic angiotensin converting enzyme 2 expression in rats with steatohepatitis. Ann Hepatol. 2013 NovDec;12(6):892-900.

75. Salem ESB, Grobe N, Elased KM. Insulin treatment attenuates renal ADAM17 and ACE2 shedding in diabetic Akita mice. Am J Physiol-Ren Physiol. 2014 Mar 15;306(6): F629-39.

76. Solerte SB, D'Addio F, Trevisan R, Lovati E, Rossi A, Pastore I, et al. Sitagliptin treatment at the time of hospitalization was associated with reduced mortality in patients with type 2 diabetes and COVID-19: a multicenter, case-control, retrospective, observational study. Diabetes Care. Diabetes Care. 2020 Dec;43(12):2999-3006.

77. Bornstein SR, Rubino F, Khunti K, Mingrone G, Hopkins D, Birkenfeld AL, et al. Practical recommendations for the management of diabetes in patients with COVID-19. Lancet Diabetes Endocrinol. 2020 Jun;8(6):546-50.

78. Diaz-Ramos A, Eilbert W, Marquez D. Euglycemic diabetic ketoacidosis associated with sodium-glucose cotransporter-2 inhibitor use: a case report and review of the literature. Int $J$ Emerg Med. Int J Emerg Med. 2019 Sep 5;12(1):27.

79. Centers for Disease Control and Prevention. Coronavirus Disease 2019 (COVID-19) and Diabetes: the importance of prevention, management, and support. Centers for Disease Control and Prevention. Available from: www.cdc.gov/coronavirus/2019ncov/cdcresponse/about-COVID-19.html. Updated July 28, 2020. [Accessed August 31, 2020].

80. Korytkowski M, Antinori-Lent K, Drincic A, Hirsch IB, McDonnell ME, Rushakoff $\mathrm{R}$, et al. A pragmatic approach to inpatient diabetes management during the COVID-19 pandemic. J Clin Endocrinol Metab. 2020 Sep 1;105(9): dgaa342.

81. Kimberly E Ng. The effect of COVID-19 on patients with diabetes. US Pharm. 2020;45(11)9-12.

82. Israelsen SB, Pottegård A, Sandholdt H, Madsbad S, Thomsen RW, Benfield T. Comparable COVID-19 outcomes with current use of GLP-1 receptor agonists, DPP-4 inhibitors or SGLT-2 inhibitors among patients with diabetes who tested positive for SARSCoV-2. Diabetes Obes Metab. 2021 Jun;23(6):1397-401

83. Das L, Dutta P. SGLT2 inhibition and COVID-19: The road not taken. Eur J Clin Invest. 2020 Dec;50(12): e13339.

84. Meyer EJ, Gabb G, Jesudason D. SGLT2 inhibitor-associated euglycemic diabetic ketoacidosis: a South Australian clinical case series and Australian spontaneous adverse event notifications. Diabetes Care. 2018 Apr;41(4): e47-9.

85. Cao X. COVID-19: immunopathology and its implications for therapy. Nat Rev Immunol. 2020 May;20(5):269-70.

86. Gupta R, Ghosh A, Singh AK, Misra A. Clinical considerations for patients with diabetes in times of COVID-19 epidemic. Diabetes Metab Syndr. 2020 May-Jun;14(3):211-2.

87. Solerte SB, Di Sabatino A, Galli M, Fiorina P. Dipeptidyl peptidase-4 (DPP4) inhibition in COVID-19. Acta Diabetol. 2020 Jul;57(7):779-83.

88. Gomez-Peralta F, Abreu C, Gomez-Rodriguez S, Barranco RJ Umpierrez GE. Safety and efficacy of DPP4 inhibitor and basal insulin in type 2 diabetes: an updated review and challenging clinical scenarios. Diabetes Ther. 2018 Oct;9(5):1775-89.

89. Rizzo M, Nikolic D, Banach M, Patti AM, Montalto G, Rizvi AA. Incretin-based therapies, glucometabolic health and endovascular inflammation. Curr Pharm Des. 2014;20(31):4953-60.

90. Rizzo M, Nikolic D, Patti AM, Mannina C, Montalto G McAdams BS, et al. GLP-1 receptor agonists and reduction of cardiometabolic risk: Potential underlying mechanisms. Biochim Biophys Acta Mol Basis Dis. 2018 Sep;1864(9 Pt B):2814-21.

91. He J, Yuan G, Cheng F, Zhang J, Guo X. Mast cell and M1 macrophage infiltration and local pro-inflammatory factors were attenuated with incretin-based therapies in obesity-related glomerulopathy. Metab Syndr Relat Disord. 2017 Sep;15(7):344-53.

92. Amin EF, Rifaai RA, Abdel-Latif RG. Empagliflozin attenuates transient cerebral ischemia/reperfusion injury in hyperglycemic rats via repressing oxidative-inflammatory-apoptotic pathway. Fundam Clin Pharmacol. 2020 Oct;34(5):548-58.

93. Ceriello A. Thiazolidinediones as anti-inflammatory and anti-atherogenic agents. Diabetes Metab Res Rev. 2008 JanFeb;24(1):14-26.

94. Deane AM, Horowitz M Comment. Is incretin-based therapy ready for the care of hospitalized patients with type 2 diabetes? Diabetes Care. 2014 Feb;37(2): e40-1.

95. Li Y, Wang M, Zhou Y, Chang J, Xian Y, Mao L, et al. Acute cerebrovascular disease following COVID-19: a single center, retrospective, observational study. 2020 Sep;5(3):279-84.

96. Bangash MN, Patel J, Parekh D. COVID-19 and the liver: little cause for concern. Lancet Gastroenterol Hepatol. 2020 Jun;5(6):529-30.

97. Tadic M, Cuspidi C, Sala C. COVID-19 and diabetes: Is there enough evidence? J Clin Hypertens (Greenwich). 2020 Jun;22(6):943-8.

98. Smith GD, Amos TA, Mahler R, Peters TJ. Effect of chloroquine on insulin and glucose homoeostasis in normal subjects and patients with non-insulin-dependent diabetes mellitus. Br Med J (Clin Res Ed). 1987 Feb 21;294(6570):465-7.

99. Quatraro A, Consoli G, Magno M, Caretta F, Nardozza A, Ceriello A, et al. Hydroxychloroquine in decompensated, treatment-refractory noninsulin-dependent diabetes mellitus. A new job for an old drug? Ann Intern Med. 1990 May 1;112(9):678-81. 
COVID-19

100. Chakravarti HN, Nag A. Efficacy and safety of hydroxychloroquine as add-on therapy in uncontrolled type 2 diabetes patients who were using two oral antidiabetic drugs. J Endocrinol Invest. 2021 Mar;44(3):481-92.

101. Gautret P, Lagier J-C, Parola P, Hoang VT, Meddeb L, Mailhe $\mathrm{M}$, et al. Hydroxychloroquine and azithromycin as a treatment of COVID-19: results of an open-label non-randomized clinical trial. Int J Antimicrob Agents. 2020 Jul;56(1):105949.

102. Rekedal LR, Massarotti E, Garg R, Bhatia R, Gleeson T, Lu B, Solomon DH. Changes in glycosylated hemoglobin after initiation of hydroxychloroquine or methotrexate treatment in diabetes patients with rheumatic diseases. Arthritis Rheum. 2010 Dec;62(12):3569-73.

103. Gerstein HC, Thorpe KE, Taylor DW, Haynes RB. The effectiveness of hydroxychloroquine in patients with type 2 diabetes mellitus who are refractory to sulfonylureas - a randomized trial. Diabetes Res Clin Pract. 2002 Mar;55(3):209-19.

104. Emami J, Pasutto FM, Mercer JR, Jamali F. Inhibition of insulin metabolism by hydroxychloroquine and its enantiomers in cytosolic fraction of liver homogenates from healthy and diabetic rats. Life Sci. 1999;64(5):325-35.

105. Penlioglou T, Papachristou S, Papanas N. COVID-19 and diabetes mellitus: May old anti-diabetic agents become the new philosopher's stone? Diabetes Ther. 2020 May 7;11(6):1-3.

106. Mercuro NJ, Yen CF, Shim DJ, Maher TR, McCoy CM, Zimetbaum PJ, et al. Risk of QT interval prolongation associated with use of hydroxychloroquine with or without concomitant azithromycin among hospitalized patients testing positive for coronavirus disease 2019 (COVID-19). JAMA Cardiol. 2020 Sep 1;5(9):1036-41. Erratum in: JAMA Cardiol. 2020 Sep 1;5(9):1071.

107. Bessière $\mathrm{F}$, Roccia $\mathrm{H}$, Delinière $\mathrm{A}$, Charrière $\mathrm{R}$, Chevalier $\mathrm{P}$, Argaud L, et al. Assessment of QT intervals in a case series of patients with coronavirus disease 2019 (COVID-19) infection treated with hydroxychloroquine alone or in combination with azithromycin in an intensive care unit. JAMA Cardiol. 2020 Sep 1;5(9):1067-9.

108. Satarker S, Ahuja T, Banerjee M, E VB, Dogra S, Agarwal T, Nampoothiri M. Hydroxychloroquine in COVID-19: potential mechanism of action against SARS-CoV-2. Curr Pharmacol Rep. 2020 Aug 24:1-9.

109. Wasko MC, McClure CK, Kelsey SF, Huber K, Orchard T, Toledo FG. Antidiabetogenic effects of hydroxychloroquine on insulin sensitivity and beta cell function: a randomised trial. Diabetologia. 2015 Oct;58(10):2336-43.

110. Infante M, Ricordi C, Fabbri A. Antihyperglycemic properties of hydroxychloroquine in patients with diabetes: Risks and benefits at the time of COVID-19 pandemic. J Diabetes. 2020 Sep;12(9):659-67.

111. Gupta A. Real-world clinical effectiveness and tolerability of hydroxychloroquine $400 \mathrm{mg}$ in uncontrolled type 2 diabetes subjects who are not willing to initiate insulin therapy (HYQReal-World study). Curr Diabetes Rev. 2019;15(6):510-9.

112. Shojania K, Koehler BE, Elliott T. Hypoglycemia induced by hydroxychloroquine in a type II diabetic treated for polyarthritis J Rheumatol. 1999 Jan;26(1):195-6.

113. COVID-19 RISK and Treatments (CORIST) Collaboration. Use of hydroxychloroquine in hospitalised COVID-19 patients is associated with reduced mortality: Findings from the observational multicentre Italian CORIST study. Eur J Intern Med. 2020 Dec;82:38-47.

114. Hernandez AV, Roman YM, Pasupuleti V, Barboza JJ, White CM. Hydroxychloroquine or chloroquine for treatment or prophylaxis of COVID-19: a living systematic review. Ann Intern Med 2020 Aug 18;173(4):287-96.

115. Lim S, Bae JH, Kwon HS, Nauck MA. COVID-19 and diabetes mellitus: from pathophysiology to clinical management. Nat Rev Endocrinol. 2021 Jan;17(1):11-30.

116. Carrasco-Sánchez FJ, López-Carmona MD, Martínez-Marcos FJ Pérez-Belmonte LM, Hidalgo-Jiménez A, Buonaiuto V, et al. Admission hyperglycaemia as a predictor of mortality in patients hospitalized with COVID-19 regardless of diabetes status: data from the Spanish SEMI-COVID-19 Registry. Ann Med. 2021 Dec;53(1):103-16.

117. Mendez CE, Umpierrez GE. Pharmacotherapy for hyperglycemia in noncritically ill hospitalized patients. Diabetes Spectr. 2014 Aug; 27(3):180-8.
118. Moghissi ES, Korytkowski MT, DiNardo M, Einhorn D Hellman R, Hirsch IB, et al. American Association of Clinical Endocrinologists and American Diabetes Association consensus statement on inpatient glycemic control. Diabetes Care. 2009 Jun;32(6):1119-31.

119. Riddle MC, Buse JB, Franks PW, Knowler WC, Ratner RE, Selvin E, et al. COVID-19 in people with diabetes: urgently needed lessons from early reports. Diabetes Care. 2020 Jul;43(7):1378-81.

120. Peric S, Stulnig TM. Diabetes and COVID-19: Disease-managementpeople. Wien Klin Wochenschr. 2020 Jul;132(13-14):356-61.

121. Novack V, Eisinger M, Frenkel A, Terblanche M, Adhikari NK, Douvdevani A, et al. The effects of statin therapy on inflammatory cytokines in patients with bacterial infections: a randomized double-blind placebo controlled clinical trial. Intensive Care Med. 2009 Jul;35(7):1255-60.

122. Papazian L, Roch A, Charles PE, Penot-Ragon C, Perrin G Roulier P, et al. Effect of statin therapy on mortality in patients with ventilator-associated pneumonia: a randomized clinical trial. JAMA. 2013 Oct 23;310(16):1692-700.

123. Zhang XJ, Qin JJ, Cheng X, Shen L, Zhao YC, Yuan Y, et al. In-hospital use of statins is associated with a reduced risk of mortality among Individuals with COVID-19. Cell Metab. 2020 Aug 4;32(2):176-187.e4.

124. Chen N, Zhou M, Dong X, Qu J, Gong F, Han Y, et al. Epidemiological and clinical characteristics of 99 cases of 2019 novel coronavirus pneumonia in Wuhan, China: a descriptive study. Lancet. 2020 Feb 15;395(10223):507-13

125. Corrao S, Pinelli K, Vacca M, Raspanti M, Argano C. Type 2 diabetes mellitus and COVID-19: A narrative review. Front Endocrinol (Lausanne). 2021 Mar 31;12:609470.

126. Klok FA, Kruip MJHA, van der Meer NJM, Arbous MS, Gommers D, Kant KM, et al. Confirmation of the high cumulative incidence of thrombotic complications in critically ill ICU patients with COVID-19: An updated analysis. Thromb Res. 2020 Jul;191:148-50.

127. Connors JM, Levy JH. COVID-19 and its implications for thrombosis and anticoagulation. Blood. 2020 Jun 4;135(23):2033-40.

128. Tang N, Li D, Wang X, Sun Z. Abnormal coagulation parameters are associated with poor prognosis in patients with novel coronavirus pneumonia. J Thromb Haemost. 2020 Apr;18(4):844-7.

129. Moores LK, Tritschler T, Brosnahan S, Carrier M, Collen JF, Doerschug K, et al. Prevention, diagnosis, and treatment of VTE in patients with Coronavirus Disease 2019: CHEST guideline and expert panel report. Chest. 2020 Sep;158(3):1143-63.

130. Driggin E, Madhavan MV, Bikdeli B, Chuich T, LaracyJ, BiondiZoccai G, et al. Cardiovascular considerations for patients, health care workers, and health systems during the coronavirus disease 2019 (COVID-19) pandemic. J Am Coll Cardiol. 2020 May 12;75(18):2352-71.

131. Oxford AE, Halla F, Robertson EB, Morrison BE. Endothelial cell contributions to COVID-19. Pathogens. 2020 Sep 25;9(10):785.

132. Ferrario CM, Jessup J, Chappell MC, Averill DB, Brosnihan KB, Tallant EA, et al. Effect of angiotensin-converting enzyme inhibition and angiotensin II receptor blockers on cardiac angiotensinconverting enzyme 2. Circulation. 2005 May 24;111(20):2605-10.

133. Varga Z, Flammer AJ, Steiger P, Haberecker M, Andermatt R, Zinkernagel AS, et al. Endothelial cell infection and endotheliitis in COVID-19. Lancet. 2020 May 2;395(10234):1417-8.

134. Fei Y, Tang N, Liu H, Cao W. Coagulation Dysfunction. Arch Pathol Lab Med. 2020 Oct 1;144(10):1223-9.

135. Iba T, Levy JH, Wada H, Thachil J, Warkentin TE, Levi M. Subcommittee on disseminated intravascular coagulation Differential diagnoses for sepsis-induced disseminated intravascular coagulation: communication from the SSC of the ISTH. J Thromb Haemost. 2019 Feb;17(2):415-9.

136. Chung WS, Lin CL, Kao CH. Diabetes increases the risk of deepvein thrombosis and pulmonary embolism. A population-based cohort study. Thromb Haemost. 2015 Oct;114(4):812-8.

137. Zhao Z, Wang S, Ma W, Kong G, Zhang S, Tang Y, et al. Diabetes mellitus increases the incidence of deep vein thrombosis after total knee arthroplasty. Arch Orthop Trauma Surg. 2014 Jan;134(1):79-83.

138. Galanaud JP, Bertoletti L, Amitrano M, Fernández-Capitán C, Pedrajas JM, Rosa V, et al. Predictors of post-thrombotic ulcer after acute DVT: The RIETE registry. Thromb Haemost. 2018 Feb;118(2):320-8 
139. Olesen KKW, Madsen M, Gyldenkerne C, Thrane PG, Würtz M, Thim T, et al. Diabetes mellitus is associated with increased risk of ischemic stroke in patients with and without coronary artery disease. Stroke. 2019 Dec;50(12):3347-54.

140. Overvad TF, Skjøth F, Lip GY, Lane DA, Albertsen IE, Rasmussen LH, et al. Duration of diabetes mellitus and risk of thromboembolism and bleeding in atrial fibrillation: Nationwide Cohort Study. Stroke. 2015 Aug;46(8):2168-74.

141. Arepally GM, Ortel TL. Changing practice of anticoagulation: will target-specific anticoagulants replace warfarin? Annu Rev Med. 2015;66:241-53.

142. Tang N, Bai H, Chen X, Gong J, Li D, Sun Z. Anticoagulant treatment is associated with decreased mortality in severe coronavirus disease 2019 patients with coagulopathy. J Thromb Haemost. 2020 May;18(5):1094-9.

143. Lim S, Lee GY, Park HS, Lee DH, Tae Jung O, Kyoung Min K, et al. Attenuation of carotid neointimal formation after direct delivery of a recombinant adenovirus expressing glucagon-like peptide-1 in diabetic rats. Cardiovasc Res. 2017 Feb;113(2):183-94.

144. Vinué Á, Navarro J, Herrero-Cervera A, García-Cubas M, Andrés-Blasco I, Martínez-Hervás S, et al. The GLP-1 analogue lixisenatide decreases atherosclerosis in insulin-resistant mice by modulating macrophage phenotype. Diabetologia. 2017 Sep;60(9):1801-12.

145. Gerstein HC, Colhoun HM, Dagenais GR, Diaz R, Lakshmanan M, Pais P, et al. Dulaglutide and cardiovascular outcomes in type 2 diabetes (REWIND): a double-blind, randomised placebocontrolled trial. Lancet. 2019 Jul 13;394(10193):121-30.

146. Li H, Zhou Y, Zhang M, Wang H, Zhao Q, Liu J. Updated approaches against SARS-CoV-2. Antimicrob agents chemother. 2020; AAC.00483-20.

147. Rekedal LR, Massarotti E, Garg R, Bhatia R, Gleeson T, Lu B Solomon DH. Changes in glycosylated hemoglobin after initiation of hydroxychloroquine or methotrexate treatment in diabetes patients with rheumatic diseases. Arthritis Rheum. 2010 Dec;62(12):3569-73.

148. Katulanda P, Dissanayake HA, Ranathunga I, Ratnasamy V Wijewickrama PSA, Yogendranathan N, et al. Prevention and management of COVID-19 among patients with diabetes: an appraisal of the literature. Diabetologia. 2020 May 14;1-13.

149. Deane AM, Horowitz M Comment. Is incretin-based therapy ready for the care of hospitalized patients with type 2 diabetes? Diabetes Care. 2014 Feb;37(2): e40-1

150. Inzucchi SE, Bergenstal RM, Buse JB Diamant M, Ferrannini E Nauck M, et al. Management of hyperglycemia in type 2 diabetes: a patient-centered approach: Position statement of the American Diabetes Association (ADA) and the European Association for the Study of Diabetes (EASD). Diabetes Care. 2012 Jun;35(6):1364-79.

151. Ortolani C, Pastorello EA. Hydroxychloroquine and dexamethasone in COVID-19: who won and who lost? Clin Mol Allergy. 2020 Sep 9;18:17.

152. Asselah T, Durantel D, Pasmant E, Lau G, Schinazi RF. COVID-19: Discovery, diagnostics and drug development. J Hepatol. 2021 Jan;74(1):168-84

153. Angus DC, Derde L, Al-Beidh F, Annane D, Arabi Y, Beane A, et al. Effect of hydrocortisone on mortality and organ support in patients with severe COVID-19: The REMAP-CAP COVID-19 Corticosteroid Domain Randomized Clinical Trial. JAMA. 2020 Oct 6;324(13):1317-29.

154. Smith GD, Amos TA, Mahler R, Peters TJ. Effect of chloroquine on insulin and glucose homoeostasis in normal subjects and patients with non-insulin-dependent diabetes mellitus. Br Med J (Clin Res Ed). 1987 Feb 21;294(6570):465-7.

155. Russell CD, Millar JE, Baillie JK. Clinical evidence does not support corticosteroid treatment for 2019-nCoV lung injury. Lancet. 2020 Feb 15;395(10223):473-5.

156. Clore JN, Thurby-Hay L. Glucocorticoid-induced hyperglycemia. Endocr Pract. 2009 Jul-Aug;15(5):469-74.

157. Anesi GL, Manaker S, Finlay G. Coronavirus disease 2019 (COVID-19): Critical care issues. UpToDate. Available from: https://www.uptodate.com/contents/coronavirus-disease-2019covid-19-critical-care-issues? [Accessed 27st May 2021].

158. Prescott HC, Rice TW. Corticosteroids in COVID-19 ARDS Evidence and hope during the pandemic. JAMA. 2020 Oct 6;324(13):1292-5.
159. Sinha N, Balayla G. Hydroxychloroquine and COVID-19. Postgrad Med J. 2020 Sep;96(1139):550-5.

160. Caly L, Druce JD, Catton MG, Jans DA, Wagstaff KM. The FDAapproved drug ivermectin inhibits the replication of SARS-CoV-2 in vitro. Antiviral Res. 2020 Jun;178:104787.

161. Sreekanth Reddy O, Lai WF. Tackling COVID-19 using remdesivir and favipiravir as therapeutic options. Chembiochem. 2021 Mar 16;22(6):939-48

162. Jorgensen SCJ, Kebriaei R, Dresser LD. Remdesivir: Review of pharmacology, pre-clinical data, and emerging clinical experience for COVID-19. Pharmacotherapy. $2020 \mathrm{Jul} ; 40(7): 659-71$.

163. Joensen LE, Madsen KP, Holm L, Nielsen KA, Rod MH, Petersen AA, et al. Diabetes and COVID-19: psychosocial consequences of the COVID-19 pandemic in people with diabetes in Denmark-what characterizes people with high levels of COVID-19-related worries? Diabet Med. 2020 Jul;37(7):1146-54.

164. Singh AK, Singh A, Singh R, Misra A. Remdesivir in COVID-19: A critical review of pharmacology, pre-clinical and clinical studies. Diabetes Metab Syndr. 2020 Jul-Aug;14(4):641-8.

165. Chu CM, Cheng VCC, Hung IFN, Wong MML, Chan KH, Chan KS, et al. Role of lopinavir/ritonavir in the treatment of SARS: initial virological and clinical findings. Thorax. 2004 Mar;59(3):252-6.

166. Hull MW, Montaner JSG. Ritonavir-boosted protease inhibitors in HIV therapy. Ann Med. 2011 Aug;43(5):375-88.

167. Verdugo-Paiva F, Izcovich A, Ragusa M, Rada G. Lopinavirritonavir for COVID-19: A living systematic review. Medwave. 2020 Jul 15;20(6): e7967.

168. American Diabetes Association. 15. Diabetes care in the hospital: Standards of medical care in diabetes-2021. Diabetes Care. 2021 Jan;44(Suppl 1): S211-S220.

169. Echecopar-Sabogal J, D’Angelo-Piaggio L, Chanamé-Baca DM, Ugarte-Gil C. Association between the use of protease inhibitors in highly active antiretroviral therapy and incidence of diabetes mellitus and/or metabolic syndrome in HIV-infected patients: A systematic review and meta-analysis. Int J STD AIDS. 2018 Apr;29(5):443-52.

170. Liu X, Chen H, Shang Y, Zhu H, Chen G, Chen Y, et al. Efficacy of chloroquine versus lopinavir/ritonavir in mild/general COVID-19 infection: a prospective, open-label, multicenter, randomized controlled clinical study. Trials. $2020 \mathrm{Jul} \mathrm{8;21(1):622.}$

171. Cao B, Wang Y, Wen D, Liu W, Wang J, Fan G, et al A trial of lopinavir-ritonavir in adults hospitalized with severe Covid-19. N Engl J Med. 2020 May 7;382(19):1787-99.

172. Pardi N, Hogan MJ, Porter FW, Weissman D. mRNA vaccines - a new era in vaccinology. Nat Rev Drug Discov. 2018 Apr;17(4):261-79.

173. Hodgson J. The pandemic pipeline. Nat Biotechnol. 2020 Mar 20;38(5):523-32.

174. Parnham MJ, Haber VE, Giamarellos-Bourboulis EJ, Perletti G, Verleden GM, Vos R. Azithromycin: Mechanisms of action and their relevance for clinical applications. Pharmacol Ther. 2014 Aug;143(2):225-45

175. Arshad S, Kilgore P, Chaudhry ZS, Jacobsen G, Wang DD, Huitsing $\mathrm{K}$, et al. Treatment with hydroxychloroquine, azithromycin, and combination in patients hospitalized with COVID-19. Int J Infect Dis. 2020 Aug;97:396-403

176. Goldstein EJC, Owens Jr RC, Nolin TD. Antimicrobial-associated QT interval prolongation: pointes of interest. Clin Infect Dis. 2006 Dec 15;43(12):1603-11.

177. Ray WA, Murray KT, Hall K, Arbogast PG, Stein CM. Azithromycin and the risk of cardiovascular death. N Engl J Med. 2012 May 17;366(20):1881-90.

178. Baker WL, Couch KA. Azithromycin for the secondary prevention of coronary artery disease: a meta-analysis. Am J Health Syst Pharm. 2007 Apr 15;64(8):830-6.

179. Svanström H, Pasternak B, Hviid A. Use of azithromycin and death from cardiovascular causes. N Engl J Med. 2013 May $2 ; 368(18): 1704-12$

180. Fernández-Cuadros ME, Albaladejo-Florín MJ, Álava-Rabasa S, Gallego-Galiana J, Pérez-Cruz GF, Usandizaga-Elio I, et al. Compassionate use of rectal ozone (O3) in severe COVID-19 pneumonia: a case-control study. SN Compr Clin Med. 2021 Mar 22:1-15.

181. Zhou Y, Vedantham P, Lu K, Agudelo J, Carrion R Jr, Nunneley JW, 
COVID-19

et al. Protease inhibitors targeting coronavirus and filovirus entry. Antiviral Res. 2015 Apr;116:76-84.

182. RECOVERY Collaborative Group, Horby P, Lim WS, Emberson JR Mafham M, Bell JL, et al. Dexamethasone in hospitalized patients with Covid-19. N Engl J Med. 2021 Feb 25;384(8):693-704.

183. Tomazini BM, Maia IS, Cavalcanti AB, Berwanger O, Rosa RG Veiga VC, et al. Effect of dexamethasone on days alive and ventilator-free in patients with moderate or severe acute respiratory distress syndrome and COVID-19: The CoDEX Randomized Clinical Trial. JAMA. 2020 Oct 6;324(13):1307-16.

184. Gautret P, Million M, Jarrot PA, Camoin-Jau L, Colson P, Fenollar F, et al. Natural history of COVID-19 and therapeutic options. Expert Rev Clin Immunol. 2020 Dec; 16(12):1159-84.

185. Rubino F, Amiel SA, Zimmet P, Alberti G, Bornstein S, Eckel RH, et al. New-Onset Diabetes in Covid-19. N Engl J Med. 2020 Aug 20;383(8):789-90

\section{Diabetes mellitus and COVID-19: modern views on pathogenetic issues of clinic and therapy}

\author{
V.I. Tsymbalyuk', M.D. Tronko², Yu.G. Antypkin ${ }^{3}$, \\ V.V. Popova ${ }^{2}$ \\ 'National Academy of Medical Sciences of Ukraine \\ ${ }^{2} \mathrm{SI}$ «V.P. Komissarenko Institute of Endocrinology and Metabolism of NAMS \\ of Ukraine» \\ ${ }^{3} \mathrm{SI}$ «Institute of Pediatrics, Obstetrics and Gynecology named acad. \\ O.M. Lukyanova of NAMS of Ukraine»
}

\begin{abstract}
Patients with diabetes mellitus have been in the spotlight since the early stages of the pandemic, as growing epidemiological data suggest that they are at increased risk of severe clinical consequences of COVID-19. As the global COVID-19 pandemic continues to evolve, it is becoming increasingly clear that the link between COVID-19 and diabetes mellitus is a complex pathophysiological interaction. The effects of COVID-19 are more severe in patients with diabetes, which can accelerate the onset of acute metabolic complications such as diabetic ketoacidosis and hyperglycemia. The mechanisms underlying these linkages remain unclear, but they apparently include the angiotensin-converting enzyme 2 receptor, the binding site for severe acute respiratory syndrome (SARS-CoV-2) coronavirus 2 in key metabolic organs, in particular, in $\beta$-cells of the pancreas. Potentially tropism of SARSCoV-2 to $\beta$-cells can lead to cell damage and impaired insulin secretion, causing hyperglycemia and ketoacidosis. Understanding the two-way interaction between diabetes and COVID-19 will be critical to the prevention and treatment of diabetic patients. Currently available epidemiological data on COVID-19 do not support the hypothesis that diabetic patients are at increased risk of infection compared to the general population. To date, it has been established that decompensated diabetes is an independent factor that aggravates the course of coronavirus infection and significantly increases the risk of fatal disease. The review presents the quintessence of the evolution of views of pathogenetic and clinical aspects of understanding the mechanisms of this pathological tandem, as well as therapeutic strategies for the treatment of patients with COVID-19 and diabetes mellitus. As the incidence of diabetes mellitus continues to rise worldwide, it is now, more than
\end{abstract}

ever, that diabetes prevention and control must become a priority in the health systems of all countries.

Keywords: COVID-19, diabetes mellitus, pathogenesis, clinic, treatment.

\section{Сахарный диабет и COVID-19: современные взгляды на патогенетические вопросы клиники и терапии}

\author{
В.И. Цымбалюк', Н.Д. Тронькоㄹ, Ю.Г. Антипкин", \\ В.В. Попова ${ }^{2}$ \\ 'Национальная академия медицинских наук Украины \\ 2ГУ «Институт эндокринологии и обмена веществ им. В.П. Комиссаренко \\ НАМН Украины» \\ ${ }^{3} Г У$ «Институт педиатрии, акушерства и гинекологии им. акад. \\ Е.Н. Лукьяновой НАМН Украины»
}

Резюме. Пациенты с сахарным диабетом (СД) находятся в центре внимания с ранних стадий пандемии, поскольку растущие эпидемиологические данные показывают, что они подвержены более высокому риску тяжелых клинических исходов COVID-19. По мере того как глобальная пандемия COVID-19 продолжает развиваться, становится все более очевидным, что взаимодействие между COVID-19 и СД представляет собой сложное патофизиологическое взаимодействие. Исходы COVID-19 более тяжелые у пациентов с СД, который способен ускорить возникновение острых метаболических осложнений заболевания, таких как диабетический кетоацидоз и гипергликемия. Эти механизмы, лежащие в основе этих связей остаются неясными, но они, очевидно, включают рецептор ангиотензинпревращающего фермента 2, сайт связывания для коронавируса 2 тяжелого острого респираторного синдрома (SARSCoV-2), который экспрессируется в ключевых метаболических органах, в частности, в ß-клетках поджелудочной железы. Потенциально тропизм SARS-CoV-2 к $\beta$-клеткам может привести к повреждению клеток и нарушению секреции инсулина, вызывая гипергликемию и кетоацидоз. Понимание двунаправленного взаимодействия между CД и COVID-19 будет иметь решающее значение для профилактики и лечения пациентов с СД. Имеющиеся на данный момент эпидемиологические данные по COVID-19 не подтверждают гипотезу о том, что пациенты с СД подвержены повышенному риску инфицирования по сравнению с общей популяцией. На сегодняшний день установлено, что декомпенсированный СД является независимым фактором, отягощающим течение коронавирусной инфекции и достоверно повышающим риски фатального исхода заболевания. В обзоре представлена квинтэссенция эволюции взглядов патогенетических и клинических аспектов понимания механизмов данного патологического тандема, а также терапевтических стратегий лечения пациентов с COVID-19 и СД. Поскольку уровень заболеваемости СД продолжает расти во всем мире, сейчас, более чем когдалибо, профилактика СД и борьба с ним должны стать приоритетом систем здравоохранения всех стран мира.

Ключевые слова: COVID-19, сахарный диабет, патогенез, клиника, лечение. 
Для цитування: Цимбалюк ВІ, Тронько МД, Антипкін ЮГ, Попова BB. Цукровий діабет і COVID-19: сучасні погляди на патогенетичні питання клініки та терапії. Ендокринологія. 2021;26(3):227-247. DOI: 10.31793/1680-1466.2021.26-3.227.

Адреса для листування: Попова Вікторія Василівна, popovavv27@gmail.com, ДУ «Інститут ендокринології та обміну речовин ім. В.П. Комісаренка НАМН України», вул. Вишгородська, 69, Київ 04114, Україна.

Відомості про авторів: Цимбалюк Віталій Іванович, д-р мед. наук, проф., чл.-кор. НАН України, акад. НАМН України, Президент HAMH України, ORCID: 0000-0001-7544-6603; Тронько Микола Дмитрович, д-р мед. наук, проф., чл.-кор. НАН України, акад. НАМН України, завідувач відділу фундаментальних і прикладних проблем ендокринології, директор ДУ «Інститут ендокринології та обміну речовин ім. В.П. Комісаренка НАMH України», ORCID: 0000-0001-7421-0981; Антипкін Юрій Геннадійович, д-р мед. наук, проф., акад. НАМН України, академік-секретар відділення клінічної медицини НАМН України, директор ДУ «Інститут педіатрії, акушерства і гінекології ім. О.М. Лук'янової НАMH України», ORCID: 0000-0002-8018-4393; Попова Вікторія Василівна, д-р мед. наук, завідувачка відділу профілактичної діабетології ДУ «Інститут ендокринології та обміну речовин ім. В.П. Комісаренка НАМН України», ORCID:0000-0002-4116-0671.

Особистий внесок: Цимбалюк В.І. — керівництво, контроль і рецензування статті; Тронько М.Д. - ідея роботи й консультація під час редагування статті; Антипкін Ю.Г. - аналіз літературних джерел і написання тексту; Попова В.В. - вивчення літератури по темі, аналіз літературних джерел і написання тексту.

Фінансування: стаття підготована в рамках бюджетного фінансування НАМН України за планом науково-дослідних робіт ДУ «Інститут ендокринології та обміну речовин ім. В.П. Комісаренка НАМН України».

Декларація з етики: автори задекларували відсутність конфлікту інтересів і фінансових зобов'язань.

Стаття: надійшла до редакції 04.06 .2021 р.; перероблена 30.09.2021 р.; прийнята до друку 01.10.2021 р.; надрукована 20.10.2021 p.

For citation: Tsymbalyuk VI, Tronko MD, Antipkin YuG, Popova VV. Diabetes mellitus and COVID-19: modern views on pathogenetic issues of clinic and therapy. Endokrynologia. 2021;26(3):227-247. DOI: 10.31793/1680-1466.2021.26-3.227.

Correspondence address: Popova Victoria Vasylivna, popovavv27@gmail.com, State Institution «V.P. Komisarenko Institute of Endocrinology and Metabolism of the NAMS of Ukraine», Vyshgorodska str., 69, Kyiv 04114, Ukraine.

Information about the authors: Tsymbalyuk Vitaly Ivanovich, Dr. Sci. (Medicine), Prof., Cor. Member of the NAS of Ukraine, Acad. of the NAMS of Ukraine, President of the NAMS of Ukraine, ORCID: 00000001-7544-6603; Tronko Mykola Dmytrovych, Dr. Sci. (Medicine), Prof., Cor. Member of the NAS of Ukraine, Acad. of the NAMS of Ukraine, Head of the Department of Fundamental and Applied Problems of Endocrinology, Director of the State Institution «V.P. Komisarenko Institute of Endocrinology and Metabolism of the NAMS of Ukraine», ORCID: 0000-0001-7421-0981; Antypkin Yuriy Gennadievich, Dr. Sci. (Medicine), Prof., Acad. of the NAMS of Ukraine, AcademicianSecretary of the Department of Clinical Medicine of the National Academy of Medical Sciences of Ukraine, Director of the State Institution «A.N. Lukyanova Institute of Pediatrics, Obstetrics and
Gynecology of the NAMS of Ukraine», ORCID: 0000-0002-8018-4393; Popova Victoria Vasylivna, Dr. Sci. (Medicine), Head of the Department of Preventive Diabetology, State Institution «V.P. Komisarenko Institute of Endocrinology and Metabolism of the NAMS of Ukraine», ORCID: 0000-0002-4116-0671.

Personal contribution: Tsymbalyuk V.I. - management, control and review of article; Tronko M.D. - idea of work and consultations when editing an articl; Antypkin Yu.G. - analysis of literary sources and text writing; Popova V.V. - study of literature on the topic, analysis of literary sources and text writing.

Funding: The article was prepared within the framework of budgetary funding of the National Academy of Medical Sciences of Ukraine according to the plan of research work of the State Institution «V.P. Komisarenko Institute of Endocrinology and Metabolism of the NAMS of Ukraine».

Declaration of Ethics: The authors have declared no conflicts of interest or financial obligations.

Article: received 04 June 2021; revised 30 September 2021; accepted 01 October 2021; published 20 October 2021.

Для цитирования: Цымбалюк ВИ, Тронько НД, Антипкин ЮГ, Попова BB. Сахарный диабет и COVID-19: современные взгляды на патогенетические вопросы клиники и терапии. Эндокринология. 2021;26(3):227-247. DOI: 10.31793/1680-1466.2021.26-3.227.

Адрес для переписки: Попова Виктория Васильевна, popovavv27@gmail.com, ГУ «Институт эндокринологии и обмена веществ им. В.П. Комиссаренко НАМН Украины», ул. Вышгородская, 69, Киев 04114, Украина.

Сведения об авторах: Цымбалюк Виталий Иванович, д-р мед. наук, проф., чл.-корр. НАН Украины, акад. НАМН Украины, Президент НАMH Украины, ORCID: 0000-0001-7544-6603; Тронько Николай Дмитриевич, д-р мед. наук, проф., чл.-корр. НАН Украины, акад. НАМН Украины, заведующий отделом фундаментальных и прикладных проблем эндокринологии, директор ГУ «Институт эндокринологии и обмена веществ им. В.П. Комиссаренко НАМН Украины», ORCID: 0000-0001-7421-0981; Антипкин Юрий Геннадьевич, д-р мед. наук, проф., акад. НАМН Украины, академик-секретарь отделения клинической медицины НАМН Украины, директор ГУ «Институт педиатрии, акушерства и гинекологии им E.H. Лукьяновой HAMH Украины», ORCID: 0000-0002-8018-4393; Попова Виктория Васильевна, д-р мед. наук, заведующая отделом профилактической диабетологии ГУ «Институт эндокринологии и обмена веществ им. В.П. Комиссаренко HAMH Украины », ORCID: 0000-0002-4116-0671.

Личный вклад: Цымбалюк В.И. - руководство, контроль и рецензирование статьи; Тронько Н.Д. - идея работы и консультация при редактировании статьи; Антипкин Ю.Г. - анализ литературных источников и написания текста; Попова В.В. - изучение литературы по теме, анализ литературных источников и написания текста.

Финансирование: статья подготовлена в рамках бюджетного финансирования НАМН Украины по плану научно-исследовательских работ ГУ «Институт эндокринологии и обмена веществ им. В.П. Комиссаренко НАМН Украины».

Декларация по этике: авторы задекларировали отсутствие конфликта интересов и финансовых обязательств.

Статья: поступила в редакцию 02.06 .2021 г.; переделана 30.09.2021 г.; принята к печати 01.10.2021 г.; напечатана 20.10.2021 г. 